Discussion Paper Series A No.521

\title{
The Nested Variable Model of FDI Spillover Effects Estimation Using Hungarian Panel Data
}

\author{
Ichiro Iwasaki \\ (Institute of Economic Research, Hitotsubashi University), \\ Péter Csizmadia \\ (Institute of Sociology, Hungarian Academy of Sciences (HAS)), \\ Miklós Illéssy \\ (Institute of Sociology, HAS), \\ Csaba Makó \\ (Institute of Sociology, (HAS), \\ and \\ Miklós Szanyi \\ (Institute of World Economics, HAS)
}

May 2011

(First version: November 2009)

Institute of Economic Research

Hitotsubashi University

Kunitachi, Tokyo, 186-8603 Japan 


\title{
IER Discussion Paper Series No. A521
}

\author{
May 2011 (First version: November 2009)
}

\section{The Nested Variable Model of FDI Spillover Effects*}

\section{Estimation Using Hungarian Panel Data}

\author{
Ichiro Iwasaki, ${ }^{\mathrm{a}}$ Péter Csizmadia, ${ }^{\mathrm{b}}$ Miklós Illéssy, \\ Csaba Makó, ${ }^{b}$ and Miklós Szanyi ${ }^{\mathrm{c}}$ \\ ${ }^{a}$ Institute of Economic Research, Hitotsubashi University, Naka 2-1, Kunitachi \\ City, Tokyo 186-8603, Japan (Tel.: +81-42-580-8366; Fax: +81-42-580-8333; \\ E-mail: iiwasaki@ier.hit-u.ac.jp) (corresponding author) \\ ${ }^{\mathrm{b}}$ Institute of Sociology, Hungarian Academy of Sciences (HAS), Uri u. 49, \\ H-1014 Budapest, Hungary (E-mail: pcsizmadia@socio.mta.hu; \\ illessy@socio.mta.hu; mako@socio.mta.hu) \\ ${ }^{\mathrm{c}}$ Institute for World Economics, HAS, Orszaghaz u. 30, H-1014 Budapest, \\ Hungary (E-mail: szanyi_miklos@vki.hu)
}

\begin{abstract}
A new empirical model is presented in this paper with respect to the productivity spillover effects of foreign direct investment (FDI) by focusing on the multi-layered structure of industrial classifications. In this model, the market presence of horizontal FDI in a host country is expressed using multiple spillover variables with a nested structure corresponding to the aggregated level of industrial classification. Using large-scale firm-level data from Hungary, we estimated the nested variable model and verified horizontal FDI spillover effects that cannot be captured with the conventional model having a single horizontal variable.
\end{abstract}

Key words: foreign direct investment; multinational enterprise; technology and knowledge spillover; nested variable model; Hungary

JEL classification: D24, F21, F23, L16, L60, L80, O19, P23

\footnotetext{
* This article is the product of a Hungary-Japan joint research project titled "Multinationals and Local Resources" launched by the Institute of Economic Research, Hitotsubashi University, the Institute of Sociology, Hungarian Academy of Sciences (HAS), and the Institute of World Economy, HAS. The research was financially supported by grants-in-aid for scientific research from the Ministry of Education and Sciences of Japan (Nos. 19402023; 23243032), the Nomura Foundation for Academic Promotion, the Tokyo Maritime Kagami Memorial Foundation, and IBM Hungary. Iwasaki is much indebted to the University of Trento for a visiting fellowship at the School on Local Development from September to October 2009 funded by the EU Erasmus Mundus Scholarship. We thank Cristiano Antonelli, Bruno Dallago, Jaymin Lee for their valuable comments and suggestions as well as Jim Treadway for his editorial assistance. All remaining errors are ours.
} 


\section{Introduction}

Foreign direct investment (FDI) draws attention as a driving force of economic growth in recipient countries mainly due to two factors. One is its macroeconomic effect of boosting the effective demand of a given host country owing to the intensive capital investment and employment activity carried out by incoming foreign firms. This aspect of inward FDI has such critical significance for developing countries and post-socialist transitional states experiencing serious capital shortages that plenty of studies have been conducted on it. The other factor is its external effects on domestic firms, that is, FDI spillovers arising from the new entry into the production market of host countries and subsequent business expansion of multinational enterprises (MNEs) that have superior management know-how and advanced production technology. Because the FDI spillover effects represent a unique social phenomenon, economists have been paying considerable attention to this characteristic of FDI from theoretical and empirical perspectives. In fact, the issues concerning the relationship between MNEs and domestic firms in the host countries raised in the 1960s witnessing the advent of the age of internationalization by Brash (1966) and Katz (1969) are still stimulating many researchers today, as is obviously demonstrated by the fact that a number of microeconomic research works that empirically examine FDI spillover effects have been published in recent years with the remarkable enhancement of firm-level datasets worldwide (Görg and Strobl, 2001; Crespo and Fontoura, 2007; Mayer and Sinani, 2009).

Many economists agree that domestic firms in recipient countries gain positive externalities from FDI via the four main routes that follow. The first one is the imitation of the management system and production of MNEs. One transmission mechanism often reported in this regard is reverse engineering. Nowadays, industrial espionage is also considered to be an extreme form of imitation. The second route is the intermediate input of goods and services supplied by MNEs, which contributes to quality improvement and cost reductions in in-house products. The third route is the feedback of marketing information and transfer of techniques for quality control, inventory, and standardization through the provision of goods and services to MNEs. These foreign customers tend to actively encourage local suppliers in the form of sending experts to the latter, implementing joint research projects, and holding joint drills. The fourth route is the acquisition of human capital in the form of movement of experienced managers, engineers, and other skilled workers from MNEs to domestic firms, including not only voluntary career changes but also the active recruitment and headhunting of talent by local competitors that are quite common, in particular, in countries with a poor market for skilled labor. Now that the role of intangible assets and tacit knowledge is becoming increasingly important, the latter two routes have the same degree of 
significance as the former two in order for FDI to make positive productivity spillovers to domestic firms.

On the other hand, many researchers unanimously assert that FDI can also have a negative impact on domestic firms in the recipient countries, namely crowding-out effects, which may surpass its positive competitive effect by breaking down ineffective, monopolized domestic markets and improving the managerial discipline of indigenous companies. This is especially true when MNEs strategically attempt an all-out effort to gain a significant share in the production markets of host countries with relatively closed economies, where the level of management skills and production technology of domestic firms is significantly poorer by international standards. In this way, FDI has pros and cons for domestic firms. Thus, substantial direct capital inflows from abroad do not necessarily guarantee positive spillover effects for domestic companies. ${ }^{1}$

It is easy to imagine that post-socialist transitional countries met almost all of the above conditions to generate negative externalities from inward FDI. There have been a wide variety of empirical studies carried out regarding FDI productivity spillover effects in transition economies, including those on Hungary, referred to later, as well as those by Kinoshita (2001) on the Czech Republic, Dries and Swinnen (2004), Jensen (2004), and Marcin (2008) on Poland, Javorcik and Spatareanu (2008) and Altomonte and Pennings (2009) on Romania, Sinai and Meyer (2004) on Estonia, Javorcik (2004) on Lithuania, Yudaeva et al. (2003) on Russia, Lutz et al. (2008) on Ukraine, Hu and Jefferson (2002), Liu (2002), and Wang and Yu (2007) on China, and Konings (2001), Sabirianova et al. (2005), Gorodnichenko et al. (2007), and Kravtsova (2008) on the international comparison of several transitional countries. Nevertheless, these studies do not share the same conclusion regarding the roles of FDI in the restructuring process of domestic firms, probably because, in many transition economies, former socialist enterprises experience an enormous amount of damage from fierce competition with foreign companies.

The studies listed above presented different but interesting conclusions by turning their attention to such factors as the level of market orientation and the type of business of foreign companies (depending on whether they were foreign-owned subsidiaries or joint-venture firms), the ownership structure and the technology absorption capability of domestic firms, the geographical relationship between MNEs and domestic firms, and the market concentration, labor intensiveness, and other characteristics of each target industry in an attempt to determine why

\footnotetext{
${ }^{1}$ We do not go into the details of this issue, on which many researchers have been working for years. For more details, see excellent survey articles by Blomström and Kokko (1998) and Görg and Greenaway (2004) as well as thorough literature reviews by Javorcik (2004), Sinani and Meyer (2004), Halpern and Muraközy (2007), and Kneller and Pisu (2007).
} 
statistically significant spillover effects cannot be detected from the estimations of baseline models. On the other hand, these studies do not consider any relationship between the multi-layered structure of industrial classifications and FDI productivity spillover effects, which are the focus of this paper. To the best of our knowledge, the same can be said for preceding studies on industrialized and developing economies.

In this paper, we present a new empirical model regarding the productivity spillover effects of horizontal FDI and an estimate of the model using large-scale panel data of Hungarian firms of the early 2000s. We argue that it is not necessary for domestic firms to treat all foreign firms that come under the same category of the 2-digit level of industrial classification in a homogenous manner. The market relationship between a domestic firm and foreign counterparts has a multi-layered structure arising from the sectoral differences among firms according to the lower levels of the classification. In contrast to the conventional model to capture the market presence of horizontal FDI using a single variable, the empirical model proposed in this paper is designed to identify horizontal spillover effects on the productivity of domestic firms according to the industrial sector with different depths by expressing the FDI presence using multiple variables with a nested structure corresponding to the aggregated level of industrial classification. ${ }^{2}$ As a result of the estimation of the econometric model with the nested spillover variables in the right-hand side, which is called "the nested variable model" in this paper, we confirmed the horizontal spillover effects in Hungary simultaneously taking place in sectors with a different depth that cannot be captured with the conventional model. In other words, foreign firms in Hungary have statistically significant spillover effects on the productivity of domestic firms in the same industry, but their direction and degree differ greatly depending on proximity in product and technological space (hereinafter referred to as "industrial-technological proximity") between MNEs and domestic companies. Moreover, we found that, firstly, FDI productivity spillover effects are generated in patterns that are completely different between the manufacturing and service industries, even during the same period in the same country. Secondly, FDI exhibits different spillover effects on different productivity indicators, and thirdly, the estimation of productivity spillover effects is sensitive to the selection of business scale indices as the basis for calculating the market presence of FDI. In this sense, our empirical evidence may suggest new insights for the studies of both industrial organization and transnational investment.

\footnotetext{
${ }^{2}$ It is noteworthy that Ruane and Uğur (2004) and Haskel et al. (2007) found that the differences in the aggregate level of horizontal FDI resulted in a statistically significant gap between the estimation results of individual productivity spillover effects. Differently from the approach taken in this paper, however, they do not pay attention to the nested structure of the industrial classification.
} 
The remainder of this paper is structured as follows: Section 2 examines the relationship between the multi-layered structure of industrial classifications and productivity spillover effects of horizontal FDI. Section 3 specifies the objective and period of empirical analysis. Section 4 describes the data employed for this study. Section 5 discusses the empirical methodology. Section 6 presents the estimation results. Section 7 summarizes the major findings and concludes the paper.

\section{Multi-layered Structure of Industrial Classifications and Productivity Spillover Effects of Horizontal FDI}

To examine the productivity spillover effects of inward FDI to Hungary, we propose a new analytical framework, the essence of which is to refine the empirical methodology for estimating the externalities of horizontal FDI on the productivity of domestic firms by taking into account the multi-layered structure of industrial classifications arising from the sectoral differences among firms within an industry at the 2-digit classification level. The fundamental concept is based on our interview surveys of company managers and other executive officers of Central and Eastern European enterprises conducted in recent years in the framework of our Hungary-Japan joint research project and others. The empirical model developed in this study is based on our finding that domestic firms tend to have a substantially different scope of management interest and attitude towards MNEs operating in the same industry according to the 2-digit industrial classification, if these foreign counterparts are distinguished at a lower classification. ${ }^{3}$

Using census-type data of Hungarian firms, ${ }^{4}$ we provide a concrete example of the multi-layered structure of industrial classifications as we assume it to be. In Figure 1, we focus on a manufacturing firm (hereinafter "Company A") that is categorized as a manufacturer of plastics in primary forms according to Code 2416 of the General Industrial Classification of Economic Activities within the European Communities (NACE2416). Company A is a typical medium-sized Hungarian enterprise with 16 employees, a total turnover of 640 million Hungarian forints (HUF), and total assets of 3,200 million HUF, and $57.1 \%$ of its equity capital came from foreign investors as of 2003 .

[Figure 1]

As Figure 1 shows, Company A is surrounded by 41 firms that are also categorized as manufacturers of plastics in primary forms, of which 13 are foreign firms, including 7 fully

\footnotetext{
${ }^{3}$ We also received relevant suggestions from field studies conducted by other researchers with respect to former state-owned enterprises privatized by Western MNEs and other foreign investors in transition economies. See Estrin et al. (2000) and Stephan (2006), for instance.

${ }^{4}$ We describe the details of the data in Section 4.
} 
foreign-owned companies. These firms are hereinafter collectively referred to as "Enterprise Layer I" for brevity. The total assets, number of employees, and turnover for Enterprise Layer I, excluding Company A, are 203 billion HUF, 3,055 employees, and 173 billion HUF, and firms with foreign participation account for $25.7 \%, 23.1 \%$, and $33.5 \%$ of these figures, respectively. These 42 firms engaged in the manufacture of plastics in primary forms, including Company A, are encompassed by "Enterprise Layer II," which consists of 125 firms involved in the manufacture of basic chemicals (NACE241). Of these 125 firms, 25 are foreign, which account for $78.7 \%, 48.6 \%$, and $68.9 \%$ of the total assets, number of employees, and turnover for Enterprise Layer II, respectively. These percentages are much larger than those for firms engaged in the manufacture of plastics in primary forms. Furthermore, Enterprise Layer II is also externally surrounded by "Enterprise Layer III," consisting of 328 firms categorized as manufacturers of chemicals and chemical products (NACE 24). Of these 328 firms, 78 are foreign firms, which account for $60.7 \%$, $56.5 \%$, and $60.2 \%$ of the total assets, number of employees, and turnover for firms engaged in the manufacture of chemicals and chemical products, respectively, excluding those in the manufacture of basic chemicals.

As of 2003, Company A was involved in the manufacture of chemicals and chemical products in Hungary, together with 378 domestic firms and 116 companies with foreign participation. As indicated in Figure 1, however, Company A and these 494 enterprises outline clear boundaries differentiating the industrial groups by industrial-technological proximity. It is also clear that the FDI presence in Enterprise Layers I, II, and III is quite diverse.

The industrial-technological proximity of MNEs and domestic firms is closely related with the degree of competitiveness between the two in the product market and with the probability of the technology and knowledge transfer from the former to the latter even focusing solely on the relationship between the two operating in the same sector (Table 1). The closer the industrial sector of a domestic firm is to that of an MNE, the fiercer the market competition between the two will be, but, at the same time, the greater the possibility will be for the domestic firm to improve its productivity by acquiring good human resources through voluntary career changes and headhunting of the employees hired by the foreign firm as well as by imitating its industry-specific technology and knowledge. On the other hand, the more remote the industrial sector of a domestic firm is to that of an MNE, the more moderate the competition between the two will be, but, at the same time, the lesser the possibility will be for the domestic firm to gain industry-specific 
technology and knowledge and transfer of human capital from the foreign firm. ${ }^{5}$ Nevertheless, it may be possible for a domestic firm to significantly improve its productivity by imitating the general technology and knowledge of a sectorally remote MNE if its technology and knowledge are high level and can be utilized for wider applications to company management than those of domestic enterprises. To sum up, the spillover effects of horizontal FDI on the productivity of domestic firms emerge as the complex agglomeration effects of all of these factors.

\section{[Table 1]}

From the theoretical point of view presented above, it is easy to predict that domestic firms may receive different productivity spillover effects from horizontal FDI with different degrees of industrial-technological proximity. For instance, if market competition with MNEs operating in an outer circle (e.g., Enterprise Layer III) is in fact lower but more general technology and knowledge are transferable from these foreign companies to domestic firms, it is highly likely that positive FDI spillover effects emerge from this circle in the aggregate. In contrast, if there is significant industry-specific technology and knowledge that domestic firms can absorb from MNEs operating in Enterprise Layer I but market competition between them is so strong that this crowding effect offsets the benefits of technology and knowledge transfer, negative spillover effects may take place in this enterprise layer as a whole. Needless to say, the complete opposite situation is possible, and we can also anticipate a non-linear relationship between the FDI spillover effects and industrial-technological proximity between a domestic firm and MNEs.

In the real world, the market relationships and industrial linkages between MNEs and domestic firms are quite diverse and vary from country to country as well as industry to industry. Unless the research target is small enough, it is quite difficult, therefore, to theoretically predict the direction and degree of such external effects, and the issue has been the subject of empirical studies. Hungary is not an exceptional case.

\section{Objective and Period of Empirical Analysis}

In this section, we specify the objective and period of our empirical analysis by overlooking inward FDI to Hungary during the transition period and reviewing the preceding studies on the FDI productivity spillovers in the country.

\footnotetext{
${ }^{5}$ In comparison with blue-collar workers, however, it may be easier for management and white-collar workers to move from one company to another beyond the strictly defined boundaries of a 4-digit sector. Therefore, when we analyze an industry with a higher proportion of administrative staff in the total workforce, it is more likely that positive horizontal FDI spillovers from outer circles will be observed (i.e., Enterprise Layer II and III in Figure 1).
} 
Hungary is well known for having received a comparatively large amount of direct investment from abroad for its economic scale since the very first stage of its systemic transformation to a market economy (Iwasaki, 2007). In fact, Hungary received the largest FDI among the Central and Eastern European (CEE) countries on an accumulated total amount basis from 1990 through 1997 due to such factors as its proactive open market policy, privatization of state-owned enterprises focusing on direct sales to strategic foreign investors, and geographical proximity to Western markets. Although Hungary was overtaken by Poland as the largest FDI-recipient country in the region from 1998 onward, it received 62.7 billion USD, or 17.8\% of the total FDI that flowed into the ten CEE countries from 1990 to 2007, and its per-capita cumulative FDI for that 18-year period was 9,711 USD, the second highest after the 9,923 USD for the Czech Republic among these ten countries. ${ }^{6}$

This vast inflow of FDI led to the emergence of a mega foreign sector within the Hungarian economy. The number of firms with foreign participation almost tripled from 9,117 to 27,180, and the total amount of FDI invested in those companies jumped from 215 billion HUF to 14.833 trillion HUF from 1991 to 2007. Foreign capital actively participated not only in the manufacturing sector but also in the service sector. In 2007, the manufacturing sector had 3,264 foreign firms, or $12 \%$ of the total number of foreign firms in all industries, and attracted 5.451 trillion HUF from foreign investors, or $36.8 \%$ of the total prescribed capital amount contributed by foreign investors in all industries, whereas the service sector had 21,015 foreign firms (or $77.3 \%$ of the total) and attracted 6.436 trillion HUF (or $43.4 \%$ of the total). ${ }^{7}$

As discussed above, inward FDI to Hungary has contributed to the emergence of many foreign companies in a relatively short time, especially those in the manufacturing and services industries. The investment and business mode for MNEs has also continued to evolve over the years (Kiss, 2007). This movement may have had a significant impact on the direction and degree of the external effects of FDI on the productivity of domestic firms along with the dynamic changes in the presence of foreign companies in the domestic market and their relationship with domestic counterparts.

On the other hand, most researchers negatively evaluate the relationship between MNEs and domestic firms in Hungary by looking at the considerable disparities in financial standing and technological levels between the two and the low local procurement rate of entering firms. ${ }^{8}$ The

\footnotetext{
${ }^{6}$ Authors' calculation based on UNCTAD official data (http://stats.unctad.org/fdi/).

${ }^{7}$ Authors' calculation based on HCSO, the Statistical Year Book of Hungary (various years), and the official statistics of the Hungarian Central Statistical Office available at: http://www.ksh.hu/.

${ }^{8}$ For instance, see Farkas (2000), Szanyi (2004), Fink (2006), Acs et al. (2007), and Rugraff (2008).
} 
results of quantitative analyses concerning FDI spillover effects are also used to back up such negative assessments. As far as we surveyed with regard to this issue, 11 papers have been published in the past either devoted solely to the case study of Hungary or reporting empirical results limiting the scope of any estimation of Hungary as part of international comparative research. Table 2 contains a summary of empirical methods and estimation results in these research works. It is difficult to determine from this table that the preceding studies as a whole strongly suggest the positive spillover effects of inward FDI to Hungary on the productivity of domestic firms; this is because the estimation results of the proxies for the market presence of FDI, that is, the spillover variables representing the comparative business scale of foreign companies within each industrial sector they belong to, are mixed. There is no denial that the non-uniformity of the empirical results is largely dependent upon the differences not only in the structure of the regression models and dataset used but also in the estimation period applied because the presence of FDI and the relationship between MNEs and domestic firms in Hungary are considered to have changed dynamically at each stage of the transition to a market economy from the 1990s to the early 2000 s.

\section{[Table 2]}

With this in mind, we reexamine FDI productivity spillover effects in Hungary only for the early 2000s, during which the business activity of foreign firms entered its mature, stable stage. It is highly likely that positive FDI spillover effects during this period exceed crowding-out effects for two reasons. First, the business activity of many MNEs has taken greater root in local communities, and their alliance with domestic firms has achieved larger scale and depth through parts supply and outsourcing than before. Second, many domestic firms have improved their management practices, and the weaker ones have been forced out of business through severe market competition over the past 15 years. ${ }^{9}$ We also give great attention to the service sector, which has been completely ignored in previous studies, because, as reported above, the presence of foreign companies in services is just as remarkable as it is in the manufacturing industries and, hence, we expect that a significant amount of technology and knowledge has been transferred from MNEs to domestic firms in the service industries.

\section{Data}

The data underlying our empirical analysis are annual census-type data of Hungarian incorporated enterprises offered from the National Tax Authority of Hungary for academic research purposes.

\footnotetext{
${ }^{9}$ Studies suggesting this possibility include those by Inzelt (2008), Mako et al. (2009), and Sass et al. (2009).
} 
The data were compiled from financial statements associated with tax reporting submitted to the tax office by legal entities performing accounting and tax procedures by double-entry bookkeeping. The observation period was from 2002 through 2005. The data cover all industries, including manufacturing and service industries, ${ }^{10}$ and contain basic information for each sample firm, including the NACE 4-digit codes, annual average number of employees, total assets, turnover, and other financial indices. In addition, the locations of the sample firms are identifiable to the extent that they are divided into the capital region, the western region, and the eastern region. ${ }^{11}$

Information about the ownership structure includes the total amount of equity capital (prescribed capital) at the end of the term and its share of state, domestic, and foreign private investors. Thus, the data allow us to know whether a given sample firm is a fully domestically owned or a foreign firm and, when it is a foreign firm, whether it is a foreign joint-venture firm or a fully foreign-owned firm according to the ownership share of foreign investors in the total amount of subscribed equity.

All nominal values are deflated with the base year being 2002 to use the data. ${ }^{12}$ As Sgard (2001) and Claessens and Djankov (2002) indicate, firm-specific price deflators, which are the most desirable for deflation, are not available in Hungary. Hence, following the steps taken by these two studies, the consumer price index, the industrial producer price index, and the investment price index reported by the Hungarian Central Statistical Office are used as alternative deflators for every aspect of the empirical analysis in this paper. In addition, for using the data, samples including unrealistic and inconsistent input and missing values that pose an impediment to our empirical analysis are removed, and cleansing procedures are performed with due attention.

The data form an unbalanced panel with the new entry and exit of enterprises during the observation period. All of the effective data values concerning these newly entering and exiting firms are used for the computation of industry-level aggregated values, such as FDI spillover variables and Herfindahl indices reported later. The observations used for our empirical analysis are limited to those concerning companies with an average number of employees of five or more

\footnotetext{
${ }^{10}$ The manufacturing industries include food products and beverages through recycling (NACE 15-37). The service sector refers to wholesale and retail trade: repair of motor vehicles, motorcycles, and personal and household goods (NACE 50-52), hotels and restaurants (NACE 55), transport, storage, and communication (NACE 60-64), and real estate, renting, and business activities (NACE 71-74).

${ }^{11}$ The individual regions consist of the following city and counties: the capital region consists of Budapest and Pest County; the western region consists of the following nine counties: Győr-Moson-Sopron, Komarom-Esztergom, Vas, Veszprem, Fejer, Zala, Somogy, Tolna, and Baranya; and the eastern region also consists of nine counties: Nograd, Bacs-Kiskun, Csongrad, Bekes, Jasz-Nagykun-Szolnok, Hajdu-Bihar, Szabolcs-Szatmar-Bereg, Borsod-Abauj-Zemplen, and Heves.

${ }^{12}$ Unless otherwise specified, the unit used for the price data is 1,000 HUF.
} 
and to those available in the data at least for two terms in the analysis period in order to control a firm's individual effects using panel data estimators and to exclude so-called "one-man companies" and micro firms from our estimation. Following many previous studies, we also exclude those companies that belong to industries with less than 5 active firms at the 4-digit level from the observations used in the empirical analysis of the paper.

The original data include almost the same number of sample firms as the official statistics. As a result of data cleaning and the exclusion of small-scale companies, with respect to $2003,8,505$ manufacturing firms and 17,232 service firms remain in our dataset. According to the data and official statistics, the proportions of these sample firms in the total number of incorporated enterprises and employees for 2003 account for $23.0 \%$ and $58.4 \%$ (540,146 employees) for manufacturing firms and 9.3\% and 44.9\% (567,078 employees) for service firms, respectively. Furthermore, the sample of manufacturing firms includes 1,520 foreign firms (of which 886 are fully foreign-owned firms), and that for service firms includes 1,825 foreign firms (of which 994 are fully foreign-owned firms). The proportion of these foreign firms in the total number of samples $(13.0 \%)$ is almost identical to that of the official statistics if the company size is considered. The same has also been confirmed for the observations for the other years. In other words, the panel data used for our empirical analysis consist of samples representative for the manufacturing and service industries in Hungary.

\section{Empirical Methodology}

In this section, an empirical model is developed on the basis of the discussion in Section 2 regarding the relationship between the multi-layered structure of industrial classifications and the spillover effects of horizontal FDI on the productivity of domestic firms. The model is designed to estimate multiple variables representing the market presence of horizontal FDI according to the degree of difference in industrial-technological proximity to a domestic firm to be analyzed. As in many preceding works, our sample firms include both fully domestically owned firms and foreign joint-venture companies. In the empirical analysis, the direct effects of foreign participation on productivity of a joint-venture company are controlled by the foreign ownership share in the total amount of subscribed equity of the company.

As demonstrated in Figure 1, in the case of Hungary, which adopts the NACE industrial classifications, the presence of FDI in the manufacturing and service industries is calculated at three classification levels for each industry, and the productivity of the $i$-th domestic firm is then regressed into these horizontal spillover variables using a panel data estimator. More specifically, if the $i$-th domestic firm belongs to NACE with sector $P$ for the 4-digit level, sector $Q$ for the 3-digit 
level, and sector $R$ for the 2-digit level $1(P \in Q \in R)$, the market presence of FDI for the $i$-th domestic firm in sector $P$ is defined as follows:

$$
\operatorname{HORFDI}_{i t}=\frac{\sum_{p \text { for all } p \in P} x_{p t} \cdot F S_{p t}-x_{i t} \cdot F S_{i t}}{\sum_{p \text { for all } p \in P} x_{p t}-x_{i t}}
$$

where the subscript $t$ refers to the year, $x$ represents the business scale at the firm level, and FS stands for the ownership share held by foreign investors. As Equation (1) shows, if the $i$-th domestic firm is operating as a foreign joint-venture company, the business scale of the firm weighed by its foreign ownership share is subtracted from the numerator on the right-hand side.

The presence of foreign firms in the 3-digit aggregated level sector $Q$, excluding those categorized in the lower subsector $P$, is measured using the following formula:

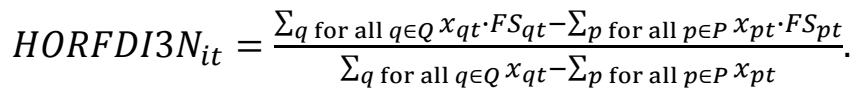

Similarly, the presence of FDI in the highest aggregated level sector $R$, excluding those categorized in the lower subsector $Q$, is given by:

$$
\text { HORFDI2N } N_{i t}=\frac{\sum_{r \text { for all } r \in R} x_{r t} \cdot F S_{r t}-\sum_{q} \text { for all } q \in Q x_{q t} \cdot F S_{q t}}{\sum_{r \text { for all } r \in R} x_{r t}-\sum_{q} \text { for all } q \in Q x_{q t}} .
$$

As is the case with the relationships among the three different enterprise layers drawn in Figure 1, the above horizontal spillover variables have a nested structure that varies depending on the level of aggregation. Namely, the numbers 2, 3, and 4 included in the names of the variables stand for the levels of aggregation in NACE, and $N$ at the end denotes that the variable has a nested structure in the relationship with the lower categories. Empirical models that comprise these nested spillover variables of horizontal FDI in the right-hand side of the estimation equation are hereinafter called "nested variable models" to distinguish them from the models with a single horizontal variable.

To compare the estimation results from the two different empirical approaches, we also estimate an additional horizontal spillover variable without giving any consideration to the multi-layered structure of industrial classifications. Specifically, the productivity variable of the $i$-th domestic firm is regressed into the market presence of FDI in sector $R$ as a whole, which is expressed in the following formula:

$$
\text { HORFDI2 } 2_{i t}=\frac{\sum_{r \text { for all } r \in R} x_{r t} \cdot F S_{r t}-x_{i t} \cdot F S_{i t}}{\sum_{r \text { for all } r \in R} x_{r t}-x_{i t}} .
$$

Furthermore, as Schoors and van der Tol (2002) and Damijan et al. (2003b) do, we also pay attention to the externalities of the vertical FDI, which consist of the backward and forward 
spillover effects generated by downstream industries and upstream industries, respectively. The backward spillover variable for the $i$-th domestic firm takes the presence of the foreign firms as its value after being weight-averaged by the share of each downstream industry in the total inputs supplied from sector $R$ as follows:

$$
B A C F D I 2_{i t}=\sum_{S \text { if } S \neq R} \alpha_{S R} \cdot\left[\frac{\sum_{s \text { for all } s \in S} x_{s t} \cdot F S_{s t}}{\sum_{s \text { for all } s \in S} x_{s t}}\right]
$$

where $\alpha_{S R}$ represents the proportion of sector R's output supplied to downstream industry $S$ at the 2-digit aggregated level. Likewise, the values of the forward spillover variable $\left(F O R F D I 2_{i t}\right)$ are calculated by weight-averaging the market presence of FDI with the proportion of each upstream industry in the total inputs of sector $R .^{13}$

We adopt three indices for the $i$-th domestic firm's productivity as the dependent variables of our regression models. As summarized in Table 2, the estimation results of the previous studies suggest the possibility that FDI has a different impact on productivity of a different nature. In this paper, we evaluate this point in detail. The first productivity variable is the output scale $(Y)$ measured using the natural logarithm of the total annual turnover. The second productivity variable is a proxy for labor productivity $(V A / L)$ using the natural logarithm of the total value added per employee. The third productivity variable is the total factor productivity (TFP) obtained as the residual of a Cobb-Douglas production function estimated using the semi-parametric method first contrived by Olley and Pakes (1996) and then developed by Levinsohn and Petrin (2003). ${ }^{14}$ Although the technical details are not given here due to space limitations, the Levinsohn-Petrin estimator is accepted as the means to accurately measure total factor productivity since it treats simultaneous bias arising from the endogenous relationship between factor inputs and productivity by adopting intermediate inputs as the firm-specific proxy of the productivity shock, which is unobservable for econometricians. By controlling for the shock, this method also solves the problem of endogeneity of input choices. ${ }^{15}$

FDI spillover effects on the productivity of domestic firms are generated on the condition that MNEs have significantly better productivity than domestic firms. Table 3 shows the results of univariate analysis regarding the productivity gap between different company groups in terms of

\footnotetext{
${ }^{13}$ These backward and forward spillover variables are computed using the input-output table for 2005 compiled by the Hungarian Central Statistical Office (HCSO, 2009).

${ }^{14}$ Petrin et al. (2004) describe how to estimate TFP using econometric software.

${ }^{15}$ According to Ackerberg et al. (2006), however, the Levinsohn-Petrin estimator may undergo collinearity problems, and, hence, there is still room for the development of the TFP estimation technique.
} 
ownership structure in the manufacturing and service industries using the above three productivity variables. We confirm that, as of 2003, foreign firms are superior to fully domestically owned firms in both sectors and in all three of the productivity variables with statistical significance at the $1 \%$ level. Moreover, the results of the analysis of variance and the Scheffe multiple comparison of the three company groups indicate that fully foreign-owned firms are superior to foreign joint-venture firms in terms of productivity in general. In both industries, however, no statistically significant differences are evident between fully foreign-owned firms and foreign joint-venture firms in terms of total factor productivity. Almost the same results as those shown in Table 3 are obtained from the analysis using 2004 and 2005 observations. Hence, we predict that FDI in Hungary had considerable potential for generating positive productivity spillover effects on domestic firms in the early 2000 s.

\section{[Tables $3 \& 4$ ]}

The observations in our regressions are limited to those of fully domestically owned firms and foreign joint-venture firms since we focus on FDI productivity spillover effects on firms established by domestic investment. To avoid possible endogeneity between firm-level productivity and the market presence of FDI that may cause the simultaneous bias on the estimation results, the total asset at the end of year $t-1$ preceding the production activity for year $t$ is used as the business scale index at the firm level, on the basis of which the FDI spillover variables are calculated. Table 4 contains the correlation matrices of six FDI spillover variables computed using the formula reported earlier. We confirm from the table that the maximum correlation coefficient among the nested horizontal spillover variables of HORFDI2N, HORFDI3N, and HORFDI4 is 0.234 , suggesting that it is unlikely for the simultaneous estimation of these three variables to bring about serious multicollinearity to the estimation results. On the other hand, as is shown in panel (a) of Table 4, the correlation coefficient for the manufacturing industry among the vertical spillover variables of BACFDI2 and FORFDI2 is 0.780 , which is greater than the threshold of 0.700 for possible multicollinearity (Lind et al., 2004). Therefore, these vertical FDI spillover variables are estimated one by one. The correlation coefficient of vertical FDI spillover variables for the service industry is 0.246 . Although it is not necessary to follow the same estimation procedure as that for the manufacturing industry, we estimate the vertical spillover variables separately for the service industry in order to compare the estimation results of the two types of industry.

Along with FDI spillover variables, we introduce three independent variables representing the input of capital stock $(K)$, labor $(L)$, and materials $(M)$ into the right-hand side of the regression model, taking the production scale as the dependent variable, and the capital-labor ratio $(K / L)$ into that of the regression model, taking labor productivity as the dependent variable. In addition to 
these input variables, we also adopt the firm's foreign ownership share (FS), government ownership share (GS), export propensity (export/total turnover) (EXPPRO), Herfindahl index at the NACE 4-digit level as the proxy for the market concentration of the sector the firm belongs to (HHI), location fixed-effects (i.e., the fixed effects of the western region and the eastern region), and year fixed-effects for all regression models as the control variables. It is natural to assume that ownership structure and export experience will exert actual influence on the firm productivity with a certain time-lag interval. Hence, we lag all these firm-level independent variables one year. We expect that factor inputs, foreign ownership, and the linkage with the international market through export activity have a positive impact on the firm's productivity, whereas state ownership and higher market concentration of the industry the firm belongs to are negatively related to its productivity. ${ }^{16}$

To control the firms' individual effects, we used three panel data estimators: pooling OLS, random-effects, and fixed-effects estimators. The selection of the estimation results reported in this paper is carried out in accordance with the results of two model specification tests. One is the Breusch-Pagan test to examine the null hypothesis that the variance of the individual effects is zero, and the other is the Hausman test to examine the random-effects assumption (Greene, 2008).

Furthermore, it is pointed out that, when aggregate variables are used to estimate firm-level outcomes, the standard errors of the coefficients of aggregate variables may be biased downwards (Moulton, 1990; Imbens and Wooldridge, 2009). Following Boschini and Olofsgård (2007), Taylor (2007), Geishecker and Görg (2008), and many others, we, therefore, compute the standard errors for all specifications using the Huber-White sandwich estimator, which allows for the errors of the within-industry clusters of observations to be correlated independently of the between-industry errors. $^{17}$

\section{Estimation Results}

The estimation results using all observations are shown in Table 5. The definitions and the descriptive statistics of the variables used for estimation are listed in the Appendix. Table 5

\footnotetext{
${ }^{16}$ Girma et al. (2004) examine the causality between the export activity of British firms and their productivity and confirm that export is an important channel for improving the productivity of domestic firms. Iwasaki et al. (2010) verify the superiority of foreign ownership over domestic private ownership and the inferiority of government ownership compared to domestic private ownership in terms of productivity using the same data in this paper.

${ }^{17}$ As a supplementary regression analysis, we estimated the effect of each FDI spillover variable separately and computed the standard errors of its coefficient adjusted for clustering on aggregated industry and confirmed that these estimation results do not significantly differ from those reported in Section 6 .
} 
contains the 24 regression models to deal with all combinations of the two industrial sectors, the three dependent variables, and the four sets of the FDI spillover variables. Both the Breusch-Pagan and the Hausman tests rejected the null hypothesis in all cases at the $1 \%$ significance level. ${ }^{18}$ Therefore, estimates of the fixed-effects models are exclusively reported in Table 5 .

[Table 5]

The nested variable model succeeds in identifying the horizontal spillover effects originating from the different depths of the industrial sector that cannot be captured with the model having a single horizontal variable. In fact, as is shown in panel (a) of Table 5, Model [1], which adopts the conventional empirical approach, detects no statistically significant horizontal effects. The coefficient of HORFDI2 is positive, but its significance is not at the $10 \%$ level or below. On the other hand, when using Figure 1 reported earlier as the basis for the explanation, the estimation results of Model [2], which gives consideration to the multi-layered structure of industrial classifications, demonstrate that positive horizontal effects are observed for Enterprise Layers I (HORFDI4) and III (HORFDI2N) at the $10 \%$ or less significance level, whereas negative horizontal effects are generated at intermediate Enterprise Layer II (HORFDI3N) with significance at the $10 \%$ level. This outcome demonstrates that the offset phenomenon between different enterprise layers is one of the main reasons that no significant spillover effects can be captured with the market presence of horizontal FDI aggregated at the NACE 2-digit level. Similar offset effects are evident in the estimation results of Models [9] through [12] regarding horizontal spillover effects on the total factor productivity of manufacturing firms. The estimation results of Models [5] through [8] suggest that the overall horizontal FDI has positive spillover effects on the labor productivity of manufacturing firms at the NACE 2-digit level with statistical significance at the $10 \%$ level, and, when these effects are decomposed into those from each enterprise layer, the impact from Enterprise Layer I, as well as that on production scale and labor productivity, is solely found to be positive and significant at the $5 \%$ level, indicating that the nested variable model is effective to identify the more particular source of external effects of horizontal FDI.

The estimation results in panel (a) of Table 5 as a whole strongly demonstrate that there is non-linear causality between industrial-technological proximity between a domestic firm and MNEs and the spillover effects of horizontal FDI in the Hungarian manufacturing sector. We conjecture that there exists a relationship, as illustrated in Figure 2, between the positive external effects on productivity of domestic companies originated from technology and knowledge transfer

\footnotetext{
${ }^{18}$ These specification test results apply to all the other estimation results reported in this paper.
} 
from MNEs and the negative external effects caused by market competition with MNEs. ${ }^{19}$ As the figure shows, if both effects are an increasing function of industrial-technological proximity between a domestic firm and MNEs, on the one hand, the external effects of technology and knowledge transfer draw an up-ward convex curve $\left(f^{\prime}(x)>0, f^{\prime}(x)>0\right)$, and, on the other, the external effects of market competition give a down-ward convex curve $\left(f^{\prime}(x)>\right.$ $\left.0, f^{\prime}{ }^{\prime}(x)<0\right)$, it is possible that the net positive FDI spillover effects explicitly emerge in a range in which industrial-technological proximity is far enough or very close between a domestic firm and MNEs (i.e., zone P in Figure 2) while the net negative spillover effects clearly appear in an internal range of industrial-technological proximity between the two (i.e., zone N). It is likely that the nested variable model empirically captured such circumstances in the manufacturing sector of Hungary.

[Figure 2]

On the other hand, as indicated in panel (b) of Table 5, the horizontal FDI spillover effects on service firms are generated in a completely different pattern from those on manufacturing firms. We found that foreign competitors generally have negative impacts on the production scale and total factor productivity of domestic firms in the same sectors they belong to, whereas, in Enterprise Layer II, they have a positive spillover effect on the labor productivity of domestic firms with statistical significance at the $10 \%$ level. These estimation results are quite interesting, as they suggest that the market behavior of MNEs may have diverse impacts on the production performance of indigenous companies in recipient countries. ${ }^{20}$

With regard to the vertical FDI spillover effects, our regression analysis detects no statistically significant backward spillover effects on manufacturing firms, whereas it confirms significantly negative effects on the production scale and total factor productivity of service firms. As for forward FDI spillovers, their impacts are insignificant for both manufacturing and service firms.

Our estimations have produced positive and significant coefficients on the input variables. Among the control variables, as has been confirmed in many studies regarding FDI into Hungary, FS shows positive and robust estimates, particularly for manufacturing firms, suggesting that

\footnotetext{
${ }^{19}$ Positive external effects on productivity of domestic firms can also be anticipated from market competition with MNEs through the managerial discipline of local companies and other channels. Therefore, here, we refer to the negative effects of market competition in net terms.

${ }^{20}$ In some cases, such as Models [21] through [24] in panel (b) of Table 5, insignificant estimation results can be obtained if the horizontal effects are dissolved for each enterprise layer. Thus, it would be desirable to estimate conventional models as well and compare the results with the estimation results of nested variable models.
} 
foreign participation is a crucial channel for Hungarian domestic firms to improve their productivity in the manufacturing sector. The statistical significance of other control variables, namely, EXPPRO, GS, and $H H I$, never reaches the $10 \%$ level.

Table 6 shows the estimation results when classifying the observations into those for fully domestically owned firms and those for foreign joint-venture firms. The estimates reported in this table are those for FDI spillover variables only using regression models with the backward variable on the right-hand side. Table 6 reveals that fully domestically owned firms are the main recipients of external effects originating from inward FDI, whether they are positive or negative. We presume that, on average, the chances of a Hungarian foreign joint-venture firm acquiring the technology and knowledge from other MNEs are greatly diminished due to the existence of foreign ownership as a direct endogenous channel for improving its productivity and to the relatively small productivity gap with fully foreign-owned firms, as confirmed in Table 3.

\section{[Table 6]}

As explained in the preceding section, the FDI spillover variables estimated in Table 5 are calculated on the basis of total assets. In most previous studies, however, the market presence of FDI is expressed using an index other than assets. With this in mind, we also estimate the FDI spillover variables using the next four indices: (a) total turnover, (b) total added-value, (c) total equity capital, and (d) annual average number of employees. Table 7 shows the results. The table reveals that there are certain differences among individual estimation results in terms of how FDI spillover effects are generated. For instance, according to the estimation results for manufacturing firms, the productivity spillover effects of horizontal FDI are stronger within the external enterprise layers (i.e., at the Enterprise Layers II and III) than within the sector of the firms to be analyzed when turnover and added-value are used as the basic indices for the computation of FDI spillover variables. On the other hand, when equity capital and the number of employees are used as the basis to calculate the market presence of FDI, the horizontal effects generated closer (i.e., at Enterprise Layer I) to the firms to be analyzed are emphasized. As for the service industry, there are significant differences in the statistical evaluation of the spillover effects on labor productivity between cases in which turnover and added-value are used as the basic indices and those in which the number of employees is used. Different management indices capture different aspects of firm activity. The regression results reported in Table 7 indicate that the empirical evaluation of FDI spillover effects on the productivity of domestic firms greatly differs depending on what aspect of the activity of MNEs the researcher focuses on most, suggesting that careful attention should be given to the 
selection of the proxy variable for the marker presence of FDI in the recipient country as well as to the productivity indices of domestic firms.

\section{[Table 7]}

As discussed above, our estimation results are sensitive to the selection of indices as the basis for computation of FDI spillover variables. Yet the signs of the FDI spillover variables estimated at the $10 \%$ or less significance level are exactly the same among the different estimation results reported in Tables 5 and 7. Therefore, we can safely say that the FDI spillover effects repeatedly detected in different model specifications with $10 \%$ or less significance level are highly robust estimates.

\section{Conclusions}

It is not necessary for domestic firms to treat all foreign companies that come under the same category of industrial classification in a homogenous fashion. In fact, local company managers are looking at the structure of their industries in a more multi-layered manner and paying strong attention to how close or far their firms are to and from foreign counterparts in the context of industrial-technological proximity. This is our conviction, acquired through several field surveys, and it provides the basic concept for this study.

Previous empirical works on the spillover effects of inward FDI have given significant attention to the differences between horizontal and vertical FDI, whereas they have not given sufficient consideration to the internal structure of horizontal FDI itself. In this paper, a new empirical framework is presented by looking at the multi-layered structure of industrial classifications arising from the sectoral differences among firms. The essence is that the market presence of horizontal FDI, which has been traditionally treated using a single variable, is expressed as multiple variables with the nested structure corresponding to the depth of industrial classification in order to identify the horizontal spillover effects on domestic firms by the enterprise layer illustrated in Figure 1. As explained in Section 5, our empirical methodology is simple and can be used for a wide range of applications.

We estimated the new empirical model using large-scale panel data of Hungarian manufacturing and service firms for the early 2000s and succeeded in detecting FDI horizontal effects that could not be captured with the conventional model. The estimation results of the nested variable model proposed in this paper strongly suggest that foreign firms in Hungary have statistically significant spillover effects on production scale and labor productivity as well as total factor productivity of domestic firms in the same industry, but their direction and degree differ greatly between individual enterprise layers. It is impossible for the single spillover variable, which 
is aggregated at a certain industrial classification level, to capture such complex effects of horizontal FDI. ${ }^{21}$ In this sense, our paper sheds light on a blind spot in the empirical study regarding the external effects of horizontal FDI and proposes a solution to overcome this problem.

Moreover, this paper presents the following estimation results. First, FDI productivity spillover effects are generated in patterns that are completely different in different industries, that is, the manufacturing and service industries, even during the same period in the same country. Secondly, FDI exhibits different spillover effects on different productivity indicators. Thirdly, the estimation of productivity spillover effects is sensitive to the selection of business scale indices as the basis for calculating the market presence of FDI. We conclude, on the basis of the above empirical results, that the transfer of technology and knowledge from MNEs to domestic firms in a recipient country occurs on the basis of a very complex economic mechanism. Therefore, careful attention should be given to the selection of variables and the model specifications so that they fit well into the scope of a micro-economic empirical examination of FDI spillover effects.

\section{References}

Ackerberg, Daniel A., Kevin Caves and Garth Frazer, (2006), Structural identification of production functions. mimeograph.

Acs, Zoltan J., Colm O'Gorman, Laszlo Szerb and Siri Terjesen, (2007), "Could the Irish miracle be repeated in Hungary?" Small Business Economics, 28 (1-2), 123-142.

Altomonte, Carlo and Enrico Pennings, (2009), "Domestic plant productivity and incremental spillovers from foreign direct investment," Journal of International Business Studies, 40 (7), 1131-1148.

Békés, Gábor, Jörn Kleinert and Farid Toubal, (2009), "Spillovers from multinationals to heterogeneous domestic firms: Evidence from Hungary,” World Economy, 32 (10), 1408-1433.

Blomström, Magnus and Ari Kokko, (1998), "Multinational corporations and spillovers," Journal of Economic Surveys, 12 (2), 1-31.

Boschini, Anne and Anders Olofsgård, (2007), "Foreign aid: An instrument for fighting communism?" Journal of Development Studies, 43(4), 622-648.

Bosco, Maria Giovanna, (2001), "Does FDI contribute to technological spillovers and growth? A panel data analysis of Hungarian firms," Transnational Corporations, 10(1), 43-67.

Brash, Donald T. (1966), American Investment in Australian Industry. Canberra: Australian National University Press.

Claessens, Stijn and Simeon Djankov, (2002), "Privatization benefits in Eastern Europe," Journal of Public Economics, 83(3), 307-324.

Crespo, Nuno and Maria Paula Fontoura, (2007), "Determinant factors of FDI spillovers - What do we really know?" World Development, 35 (3), 410-425.

Damijan, Jože P., Mark Knell, Boris Majcen and Matija Rojec, (2003a), "The role of FDI, R\&D accumulation and trade in transferring technology to transition countries: Evidence from firm panel data for eight transition countries," Economic Systems, 27(2), 189-204.

\footnotetext{
${ }^{21}$ As in almost all preceding studies, which divide FDI into the horizontal type and the vertical type by simply using the industry classification code, the empirical analysis in this paper cannot strictly distinguish between the spillover effects of the two types of FDI either. Reconsideration of the empirical strategy is a topic reserved for future research.
} 
Damijan, Jože P., Mark Knell, Boris Majcen and Matija Rojec, (2003b), Technology transfer through FDI in top-10 transition countries: How important are direct effects, horizontal and vertical spillovers? Working Paper No. 549, William Davidson Institute, Ann Arbor: University of Michigan.

Dries, Liesbeth and Johan F. M. Swinnen, (2004), "Foreign direct investment, vertical integration, and local suppliers: Evidence from the Polish dairy sector," World Development, 32(9), 1525-1544.

Estrin, Saul, Xavier Richet, Josef C. Brada (eds.), (2000), Foreign Direct Investment in Central Eastern Europe: Case Studies of Firms in Transition. Armonk and London: M. E. Sharpe.

Farkas, Pétel, (2000), The effects of foreign direct investment on R\&D and innovation in Hungary. Working Paper No.108, Institute of World Economics, Hungarian Academy of Sciences, Budapest.

Fink, Philipp, (2006), "FDI-led growth and rising polarizations in Hungary: Quantity at the expense of quality," New Political Economy, 11(1), 47-72.

Geishecker, Ingo and Holger Görg, (2008), "Winners and losers: A micro-level analysis of international outsourcing and wages," Canadian Journal of Economics, 41(1), 243-270.

Girma, Sourafel, David Greenaway and Richard Kneller, (2004), "Does exporting increase productivity? A microeconometric analysis of matched firms," Review of International Economics, 12(5), 855-866.

Görg, Holger and David Greenaway, (2004), "Much ado about nothing? Do domestic firms really benefit from foreign direct investment?" World Bank Research Observer, 19(2), 171-197.

Görg, Holger, Alexander Hijzen and Balázs Muraközy, (2009), "The role of production technology for productivity spillovers from multinationals: Firm-level evidence for Hungary," Aussenwirtschaft, 64 (1), 19-44.

Görg, Holger and Eric Strobl, (2001), "Multinational companies and productivity spillovers: A meta-analysis," Economic Journal, 111, 723-739.

Gorodnichenko, Yuriy, Jan Svejnar and Katherine Terrell, (2007), When does FDI have positive spillovers? Evidence from 17 emerging market economies. Discussion Paper No. 6546, Center for Economic Policy Research, London.

Greene, William H., (2008), Econometric Analysis (sixth edition). Upper Saddle River, N.J.: Pearson Education International.

Halpern, László and Balázs Muraközy, (2005), Does distance matter in spillover? Discussion Paper No. 4857, Center for Economic Policy Research, London.

Halpern, László and Balázs Muraközy, (2007), "Does distance matter in spillover?" Economics of Transition, 15 (4), 781-805.

Haskel, Jonathan E., Sonia C. Pereira and Matthew J. Slaughter, (2007), "Does inward foreign direct investment boost the productivity of domestic firms?" Review of Economics and Statistics, 89(3), 482-496.

Hu, Albert G. Z. and Gray H. Jefferson, (2002), "FDI impact and spillover: Evidence from China's electronic and textile industries," World Economy, 25(8), 1063-1076.

Imbens, Guido W. and Jeffrey M. Wooldridge, (2009), "Recent developments in the econometrics of program evaluation," Journal of Economic Literature, 47(1), 5-86.

Inzelt, Annamária, (2008), "The inflow of highly skilled workers into Hungary: A by-product of FDI," Journal of Technology Transfer, 33(4), 422-438.

Iwasaki, Ichiro, (2007), "Corporate restructuring and the role of foreign direct investment in Hungary," In: Bruno Dallago and Ichiro Iwasaki (eds.), Corporate Restructuring and Governance in Transition Economies, Basingstoke: Palgrave Macmillan, 178-210.

Iwasaki, Ichiro, Miklós Szanyi, Péter Csizmadia, Miklós Illéssy and Csaba Makó, (2010), "Privatization, foreign acquisition, and firm performance: A new empirical methodology and its application to Hungary," European Journal of Comparative Economics, 7(2), 307-343

Javorcik, Beata Smarzynska, (2004), "Does foreign direct investment increase the productivity of domestic firms? In search of spillovers through backward linkages," American Economic Review, 94(3), 605-627. 
Javorcik, Beata Smarzynska and Mariana Spatareanu, (2008), "To share or not to share: Does local participation matter for spillovers from foreign direct investment?" Journal of Development Economics, 85(1-2), 194-217.

Jensen, Camilla, (2004), "Localized spillovers in the Polish food industry: The role of FDI in the development process?" Regional Studies, 38(5), 535-550.

Katz, Jorge M., (1969), Production Functions, Foreign Investment and Growth: A Study Based on the Argentine Manufacturing Sector 1946-1961. Amsterdam: North Holland Publishing.

Kinoshita, Yuko, (2001), R\&D and technology spillovers through FDI: Innovation and absorptive capacity. Discussion Paper No. 2775, Center for Economic Policy Research, London.

Kiss, Eva, (2007), "Foreign direct investment in Hungary: Industry and its spatial effects," Eastern European Economics, 45(1), 6-28.

Kneller, Richard and Mauro Pisu, (2007), "Industrial linkages and export spillovers from FDI," World Economy, 30(1), 105-134.

Konings, Jozef, (2001), "The effects of foreign direct investment on domestic firms: Evidence from firm-level panel data in emerging economies," Economics of Transition, 9(3), 619-633.

Kravtsova, Victoria, (2008), "Foreign presence and efficiency in transition economies," Journal of Production Analysis, 29(2), 91-102.

Levinsohn, James and Amil Petrin, (2003), "Estimating production functions using inputs to control for unobservables," Review of Economic Studies, 70(2), 317-341.

Lind, Douglas A., William G. Marchal and Samuel A. Wathen, (2004), Statistical Techniques in Business and Economics (twelfth edition). Irwin: McGraw-Hill.

Liu, Zhiqian, (2002), "Foreign direct investment and technology spillover: Evidence from China," Journal of Comparative Economics, 30(3), 579-602.

Lutz, Stefan, Oleksandr Talavera and Sang-Min Park, (2008), "Effects of foreign presence in a transition economy," Emerging Markets Finance and Trade, 44(5), 82-98.

HCSO (Hungarian Central Statistical Office), Magyar statistikai évkönyv. Budapest: HCSO. (various years)

HCSO, (2009), Symmetric input-output table (industry by industry): Total economy 2005. Budapest: HCSO.

Makó, Csaba, Péter Csizmadia, Miklós Illéssy, Ichiro Iwasaki and Miklós Szanyi, (2009), "Organizational innovation in the manufacturing sector and the knowledge intensive business service," Competitio (6), pp. 91-121.

Marcin, Kolasa, (2008), "How does FDI inflow affect productivity of domestic firms? The role of horizontal and vertical spillovers, absorptive capacity and competition," Journal of International Trade and Economic Development, 17(1), 155-173.

Meyer, Klaus E. and Evis Sinani, (2009), "When and where does foreign direct investment generate positive spillovers? A meta-analysis," Journal of International Business Studies, 40(7), 1075-1094.

Moulton, Brent R., (1990), "An illustration of a pitfall in estimating the effects of aggregate variables on micro units," Review of Economics and Statistics, 72(2), 334-338.

Muraközy, Balázs, (2007), "Do vertical spillovers from FDI lead to changes in markets? Firm-level evidence from Hungary," Applied Economics Quarterly, 53(2), 197-218.

Olley, G. Steven and Ariel Pakes, (1996), "The dynamics of productivity in the telecommunications equipment industry," Econometrica, 64(6), 1263-1297.

Petrin, Amil, Brian P. Poi and James Levinsohn, (2004), "Production function estimation in Stata using inputs to control for unobservables," Stata Journal, 4(2), 113-123.

Ruane, Frances and Ali Uğur, (2004), "Foreign direct investment and productivity spillovers in Irish manufacturing industry: Evidence from plant level panel data," International Journal of the Economics of Business, 11 (3), 53-66.

Rugraff, Eric, (2008), "Are the FDI policies of the Central European countries efficient?" Post-Communist Economies, 20(3), 303-316. 
Sabirianova, Klara, Katherine Terrell and Jan Svejnar, (2005), "Distance to the efficiency frontier and foreign direct investment spillovers," Journal of the European Economic Association, 3(2-3), 576-586.

Sinai, Evis and Klaus E. Meyer, (2004), "Spillovers of technology transfer from FDI: The case of Estonia," Journal of Comparative Economics, 32(3), 445-466.

Szanyi, Miklós, (2004), Külföldi tőke és ágazati versenyképesség, Mühelytanulmányok 63. Szám, Világgazdasági Kutatóintézet, Magyar Tudományos Akadémia, Budapest. (in Hungarian)

Sass, Magdolna, Miklós Szanyi, Péter Csizmadia, Miklós Illéssy, Ichiro Iwasaki and Csaba Makó, (2009), Clusters and the development of supplier networks for transnational companies. Working Paper No. 187, Institute for World Economics, Hungarian Academy of Sciences, Budapest.

Schoors, Koen and Bartoldus van der Tol, (2002), Foreign direct investment spillovers within and between sectors: Evidence from Hungarian data. Working Paper No. 157, Faculty of Economics, Ghent University, Ghent.

Sgard, Jérôme, (2001), Direct foreign investments and productivity growth in Hungarian firms, 1992-1999. Working Paper No. 425, William Davidson Institute, University of Michigan, Ann Arbor.

Stephan, Johannes (ed.), (2006), Technology Transfer via Foreign Direct Investment in Central and Eastern Europe: Theory, Method of Research and Empirical Evidence. Basingstoke: Palgrave Macmillan.

Taylor, Jim, (2007), "Estimating the impact of the specialist schools programme on secondary school examination results in England," Oxford Bulletin of Economics and Statistics, 69(4), 445-471.

Torlak, Elvisa, (2004), Foreign direct investment, technology transfer, and productivity growth in transition countries: Empirical evidence from panel data. Discussion Paper No. 26, Center of Globalization and Europeanization of the Economy, Georg-August-University of Göttingen, Göttingen.

Wang, Chengqi and Li Yu, (2007), "Do spillover benefits grow with rising foreign direct investment? An empirical examination of the case of China," Applied Economics, 39(3), 397-405.

Yudaeva, Ksenia, Konstantin Kozlov, Natalia Melentieva and Natalia Ponomareva, (2003), "Does foreign ownership matter? The Russian experience," Economics of Transition, 11(3), 383-409. 


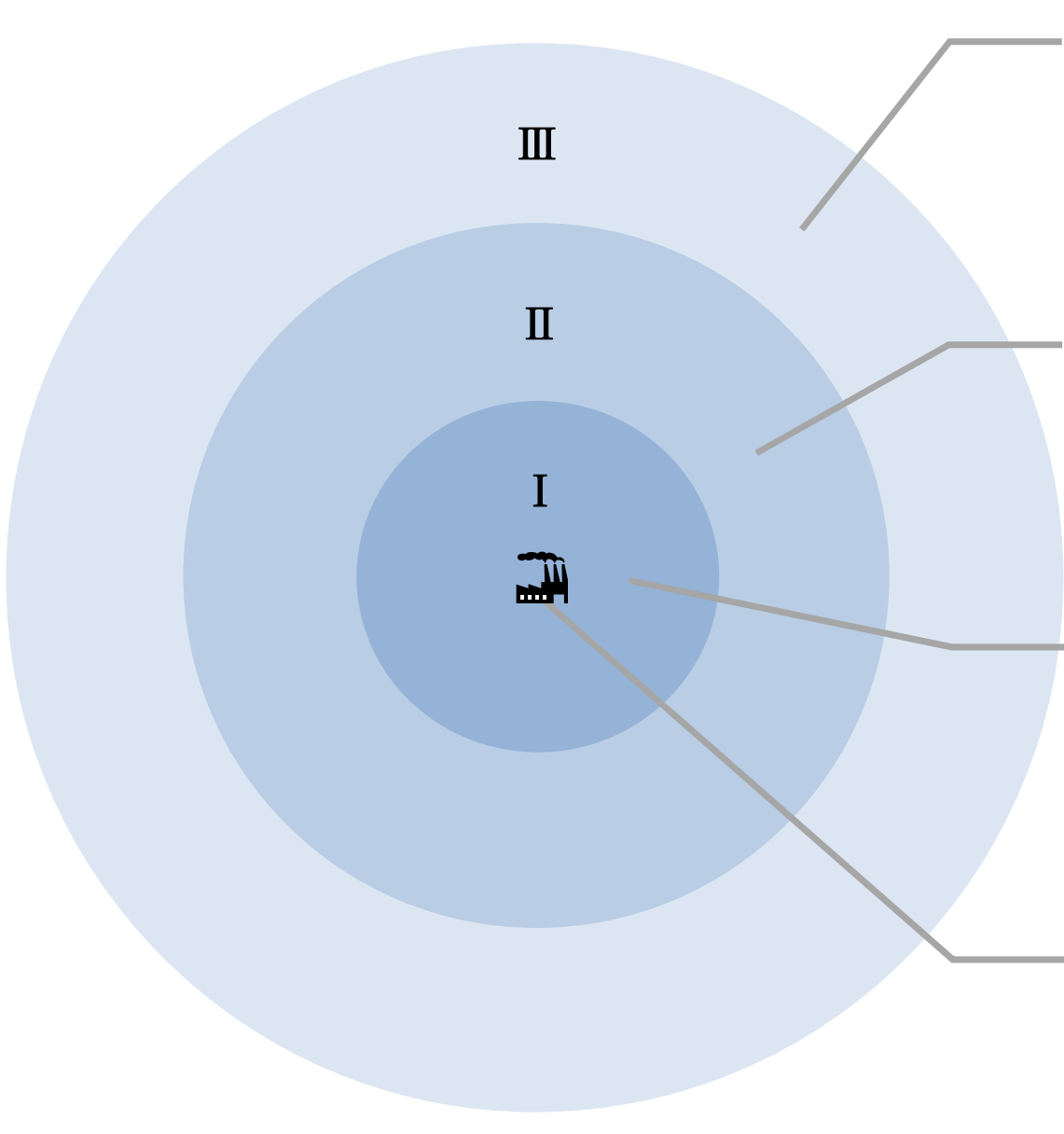

Firms classified as NACE24 engaged in the manufacture of chemicals and chemical products (except for those engaged in the manufacture of basic chemicals)

Number of firms: 328 (of which 39 are fully foreign-owned firms and 39 are foreign JV firms)

Total assets: 945 billion HUF (60.7\% of which is owned by foreign firms)

Total number of employees: 19,173 (56.5\% of whom are employed by foreign firms)

Total turnover: 518 billion HUF (60.2\% of which comes from foreign firms)

Firms classified as NACE241 engaged in the manufacture of basic chemicals (except for those engaged in the manufacture of plastics in primary forms)

Number of firms: 125 (of which 17 are fully foreign-owned firms and 8 are foreign JV firms)

Total assets: 283 billion HUF (78.7\% of which is owned by foreign firms)

Total number of employees: 8,289 (48.6\% of whom are employed by foreign firms)

Total turnover: 238 billion HUF (68.9\% of which comes from foreign firms)

\section{Firms classified as NACE2416 engaged in the manufacture of plastics in primary forms (excep for Company A) \\ Number of firms: 41 (of which 7 are fully foreign-owned firms and 6 are foreign JV firms) \\ Total assets: 203 billion HUF (25.7\% of which is owned by foreign firms) \\ Total number of employees: 3,055 (23.1\% of whom are employed by foreign firms) \\ Total turnover: 173 billion HUF (33.5\% of which comes from foreign firms)}

Source: Authors' illustration. See text for details.

Company A engaged in the manufacture of plastics in primary forms

Total assets: 320 million HUF

Foreign ownership share: $57.1 \%$

Annual average number of employees: 16 
Table 1. Relationship between industrial-technological proximity and degree of competitiveness between MNEs and domestic firms in product markets and probability of technology/knowledge transfer from MNEs to domestic firms

\begin{tabular}{|c|c|c|c|c|c|}
\hline & & \multirow{2}{*}{$\begin{array}{c}\text { Degree of } \\
\text { competitivenes } \\
\text { s between } \\
\text { MNEs and } \\
\text { domestic firms } \\
\text { in product } \\
\text { markets }\end{array}$} & \multicolumn{3}{|c|}{$\begin{array}{l}\text { Probability of technology/knowledge transfer } \\
\text { from MNEs to domestic firms }\end{array}$} \\
\hline & & & $\begin{array}{l}\text { Probability of } \\
\text { transfer of } \\
\text { human capital }\end{array}$ & $\begin{array}{l}\text { Probability of } \\
\text { transfer of } \\
\text { industry- } \\
\text { specific } \\
\text { technology and } \\
\text { knowledge }\end{array}$ & $\begin{array}{l}\text { Probability of } \\
\text { transfer of } \\
\text { general } \\
\text { technology and } \\
\text { knowledge }\end{array}$ \\
\hline \multirow{3}{*}{$\begin{array}{l}\text { Industrial- } \\
\text { technological } \\
\text { proximity }\end{array}$} & Close & Strong & High & High & \\
\hline & Moderate & Moderate & Moderate & Moderate & Homogenous \\
\hline & Far & Weak & Low & Low & \\
\hline
\end{tabular}

Source: Authors' compilation. See text for details. 
Table 2. Empirical studies on FDI productivity spillover effects in Hungary

\begin{tabular}{|c|c|c|c|c|c|c|c|c|c|c|}
\hline \multirow{3}{*}{ Author } & \multirow{3}{*}{ Sector } & \multirow{3}{*}{ Period } & \multirow{3}{*}{ Data } & \multirow{3}{*}{$\begin{array}{l}\text { Productivity } \\
\text { variable } \\
\text { (dependent } \\
\text { variable) }\end{array}$} & \multicolumn{2}{|c|}{ FDI spillover variable } & \multicolumn{3}{|c|}{ Estimation result $^{\mathrm{a}}$} & \multirow{3}{*}{ Control variables and their estimation results ${ }^{a}$} \\
\hline & & & & & \multirow{2}{*}{$\begin{array}{l}\text { Basic index } \\
\quad \text { for } \\
\text { computation }\end{array}$} & \multirow{2}{*}{$\begin{array}{l}\text { Aggregation } \\
\text { level }\end{array}$} & \multirow{2}{*}{$\begin{array}{c}\text { Horizontal } \\
\text { effects }\end{array}$} & \multicolumn{2}{|c|}{ Vertical effects } & \\
\hline & & & & & & & & $\begin{array}{l}\text { Backward } \\
\text { effects }\end{array}$ & $\begin{array}{l}\text { Forward } \\
\text { effects }\end{array}$ & \\
\hline Bosco (2001) & NA & 1993-1997 & $\begin{array}{c}\text { Panel } \\
\end{array}$ & Turnover & Turnover & NACE2 & no & NA & NA & Employment $(+)$, capital (+), foreign ownership share $(+)$ \\
\hline Sgard (2001) & $\begin{array}{l}\text { Manufacturing/co } \\
\text { nstruction }\end{array}$ & $1992-1999$ & Panel & Turnover & $\begin{array}{l}\text { Capital/turn } \\
\text { over }\end{array}$ & NACE2 & no/+ & NA & NA & $\begin{array}{l}\text { Employment }(+) \text {, capital }(+) \text {, intermediate material }(+) \text {, foreign } \\
\text { ownership share }(+)\end{array}$ \\
\hline Schoors and van der Tol (2002) & All industries & 1997-1998 & Cross-sectional & $\begin{array}{l}\text { Labor } \\
\text { productivity }\end{array}$ & Turnover & NACE2 & + & - & + & $\begin{array}{l}\text { Tangible assets to labor ratio }(+) \text {, intangible assets to labor ratio (-), } \\
\text { turnover to industrial average ratio }(+) \text {, square of turnover to } \\
\text { industrial average ratio }(-) \text {, credit interest (-), foreign ownership } \\
\text { share (+) }\end{array}$ \\
\hline Damijan et al. (2003a) ${ }^{\text {b }}$ & Manufacturing & 1994-1998 & Panel & Turnover & Turnover & NACE2 & no & NA & NA & $\begin{array}{l}\text { Employment (no), capital (+), intermediate material (+), R\&D } \\
\text { expenditure (no) }\end{array}$ \\
\hline Damijan et al. (2003b) ${ }^{b}$ & Manufacturing & 1995-1999 & Panel & Turnover & Turnover & NACE2 & no & no & no & $\begin{array}{l}\text { Employment (results not reported), capital (results not reported), } \\
\text { intermediate material (results not reported), FDI dummy }(+) \text {, dummy } \\
\text { for firms dominated by foreign investors (no), R\&D expenditure }(+)\end{array}$ \\
\hline Torlak (2004) & Manufacturing & $1994-2000$ & Panel & Turnover & Turnover & NACE2 & + & $\mathrm{NA}$ & $\mathrm{NA}$ & Employment (+), capital (+), intermediate material (+) \\
\hline Halpern and Muraközy (2005) & Manufacturing & 1996-2001 & Panel & Added-value & Turnover & NACE2 & + & + & no & $\begin{array}{l}\text { One-term lag in added-value (+), employment (results not reported), } \\
\text { capital (results not reported), intermediate material (results not } \\
\text { reported) }\end{array}$ \\
\hline Muraközy (2007) & Manufacturing & 1995-2003 & Panel & Price-cost margin & Turnover & NACE2 & - & + & no & $\begin{array}{l}\text { Herfindahl index (-), market share (no), capital productivity (no), } \\
\text { employment (-), share of imports by industry (no) }\end{array}$ \\
\hline Halpern and Muraközy (2007) & Manufacturing & 1996-2003 & Panel & $\begin{array}{l}\text { Added-value, } \\
\text { TFP (Levinson } \\
\text { and Petrin }\end{array}$ & Turnover & NACE2 & no/no & +/+ & no/no & Employment (results not reported), capital (results not reported) \\
\hline Békés et al. (2009) & Manufacturing & 1992-2003 & Panel & $\begin{array}{l}\text { TFP (Olley and } \\
\text { Pakes estimator) }\end{array}$ & Turnover & NACE2 & + & no & no & Herfindahl index (-), private ownership share (+) \\
\hline Görg et al. (2009) & Manufacturing & 1992-2003 & Panel & $\begin{array}{l}\text { Added-value, } \\
\text { TFP (Levinson } \\
\text { and Petrin }\end{array}$ & Turnover & NACE4 & $-/$ & NA & $\mathrm{NA}$ & Employment (+), capital (+) \\
\hline
\end{tabular}


Table 3. Univariate analysis of productivity gaps among different types of firm ownership, 2003

\begin{tabular}{|c|c|c|c|c|c|c|}
\hline \multirow{2}{*}{$\frac{\text { Industrial sector }}{\text { Productivity variable }}$} & \multicolumn{3}{|c|}{ Manufacturing } & \multicolumn{3}{|c|}{ Services } \\
\hline & $Y$ & $V A / L$ & TFP & $Y$ & $V A / L$ & TFP \\
\hline All firms & $\begin{array}{c}11.966 \\
(11.736)\end{array}$ & $\begin{array}{c}7.640 \\
(7.603)\end{array}$ & $\begin{array}{c}0.025 \\
(0.005)\end{array}$ & $\begin{array}{c}11.997 \\
(11.924)\end{array}$ & $\begin{array}{c}7.754 \\
(7.725)\end{array}$ & $\begin{array}{c}0.025 \\
(0.005)\end{array}$ \\
\hline Fully domestically owned firms & $\begin{array}{c}11.714 \\
(11.554)\end{array}$ & $\begin{array}{c}7.540 \\
(7.528)\end{array}$ & $\begin{array}{c}0.016 \\
(-0.001)\end{array}$ & $\begin{array}{c}11.891 \\
(11.834)\end{array}$ & $\begin{array}{c}7.676 \\
(7.656)\end{array}$ & $\begin{array}{c}0.021 \\
(0.003)\end{array}$ \\
\hline Foreign firms & $\begin{array}{c}13.144 \\
(13.115)\end{array}$ & $\begin{array}{c}8.096 \\
(8.012)\end{array}$ & $\begin{array}{c}0.065 \\
(0.039)\end{array}$ & $\begin{array}{c}12.900 \\
(12.911)\end{array}$ & $\begin{array}{c}8.411 \\
(8.476)\end{array}$ & $\begin{array}{c}0.059 \\
(0.029)\end{array}$ \\
\hline Foreign joint-venture firms & $\begin{array}{c}12.806 \\
(12.749)\end{array}$ & $\begin{array}{c}7.979 \\
(7.904)\end{array}$ & $\begin{array}{c}0.064 \\
(0.031)\end{array}$ & $\begin{array}{c}12.652 \\
(12.585)\end{array}$ & $\begin{array}{c}8.280 \\
(8.307)\end{array}$ & $\begin{array}{c}0.054 \\
(0.023)\end{array}$ \\
\hline Fully foreign-owned firms & $\begin{array}{c}13.390 \\
(13.363)\end{array}$ & $\begin{array}{c}8.180 \\
(8.091)\end{array}$ & $\begin{array}{c}0.066 \\
(0.048)\end{array}$ & $\begin{array}{c}13.106 \\
(13.165) \\
\end{array}$ & $\begin{array}{c}8.522 \\
(8.673) \\
\end{array}$ & $\begin{array}{c}0.064 \\
(0.033) \\
\end{array}$ \\
\hline $\mathrm{N}$ & 8505 & 8499 & 8461 & 17232 & 17200 & 17211 \\
\hline \multicolumn{7}{|l|}{ Comparative analysis between fully domestically owned and foreign firms } \\
\hline$t$ test on the equality of means & $-36.342^{* * *}$ & $-24.672^{* * *}$ & $-8.769^{* * *}$ & $-29.818^{* * *}$ & $-34.394^{* * *}$ & $-7.517^{* * *}$ \\
\hline Wilcoxon rank-sum test $(z)$ & $-29.933^{* * *}$ & $-22.837^{* * *}$ & $-9.366^{* * *}$ & $-25.889^{* * *}$ & $-30.775^{* * *}$ & $-8.786^{* * *}$ \\
\hline Kolmogorov-Smirnov equality-of-distributions test (combined $D$ ) & $0.381^{* * *}$ & $0.276^{* * *}$ & $0.132^{* * *}$ & $0.298^{* * *}$ & $0.360^{* * *}$ & $0.131^{* * *}$ \\
\hline \multicolumn{7}{|l|}{ Multiple group comparison of the three company groups } \\
\hline ANOVA $(F)$ & $698.280^{* * *}$ & $317.100^{* * *}$ & $38.470^{* * *}$ & 470.770 *** & $610.500^{* * *}$ & $28.760^{* * *}$ \\
\hline Bartlett test $\left(\chi^{2}\right)$ & $179.823^{* * *}$ & $23.859^{* * *}$ & $33.230^{* * *}$ & $210.567^{* * *}$ & $320.518^{* * *}$ & $235.091^{* * *}$ \\
\hline Kruskal-Wallis test $\left(\chi^{2}\right)$ & $933.501^{* * *}$ & $539.389^{* * *}$ & $88.913^{* * *}$ & $698.953^{* * *}$ & $960.198^{* * *}$ & $78.999^{* * *}$ \\
\hline \multicolumn{7}{|l|}{ Scheffe multiple comparison of the three company groups } \\
\hline Differences between fully domestically owned firms and foreign JV firms & $1.092^{* * *}$ & $0.438^{* * *}$ & $0.048^{* * *}$ & $0.762^{* * *}$ & $0.603^{* * *}$ & $0.033^{* * *}$ \\
\hline Differences between fully domestically owned firms and fully foreign-owned firn & $1.676^{* * *}$ & $0.640^{* * *}$ & $0.050^{* * *}$ & $1.215^{* * *}$ & $0.845^{* * *}$ & $0.043^{* * *}$ \\
\hline Differences between foreign JV firms and fully foreign-owned firms & $0.584^{* * *}$ & $0.202^{* * *}$ & 0.002 & $0.453^{* * *}$ & $0.242^{* * *}$ & 0.010 \\
\hline
\end{tabular}

Remarks: The upper values are means, and the lower values in parenthesis are medians. ${ }^{* *},{ }^{* *}$, and ${ }^{*}$ denote statistical significance at the $1 \%, 5 \%$, and $10 \%$ level, respectively.

Source: Authors' estimation. For definitions and descriptive statistics of the variables, see Appendix. 
Table 4. Correlation matrices of FDI spillover variables

(a) Manufacturing ( $\mathrm{N}=22736)$

\begin{tabular}{lcccccc}
\hline & HORFDI2 & HORFDI2N & HORFDI3N & HORFDI4 & BACFDI2 & FORFDI2 \\
\hline HORFDI2 & 1.000 & & & & \\
HORFDI2N & 0.742 & 1.000 & & & \\
HORFDI3N & 0.087 & -0.029 & 1.000 & & \\
HORFDI4 & 0.516 & 0.234 & -0.089 & 1.000 & \\
BACFDI2 & 0.240 & 0.213 & -0.184 & 0.259 & 1.000 \\
FORFDI2 & 0.264 & 0.261 & -0.126 & 0.201 & 0.780 \\
\hline
\end{tabular}

(b) Services ( $\mathrm{N}=48782)$

\begin{tabular}{lcccccc}
\hline & HORFDI2 & HORFDI2N & HORFDI3N & HORFDI4 & BACFDI2 & FORFDI2 \\
\hline HORFDI2 & 1.000 & & & & \\
HORFDI2N & 0.752 & 1.000 & & & \\
HORFDI3N & 0.283 & -0.015 & 1.000 & & \\
HORFDI4 & 0.291 & -0.047 & 0.094 & 1.000 & \\
BACFDI2 & -0.395 & -0.323 & -0.490 & -0.002 & 1.000 \\
FORFDI2 & 0.013 & -0.062 & -0.111 & 0.018 & 0.246 \\
\hline SOUFC: & & & & & \\
\hline
\end{tabular}

Source: Authors' calculation. For definitions and descriptive statistics of the variables, see Appendix. 
Table 5. Panel data analysis of FDI productivity spillover effects: Comparison of the conventional model and the nested variable model

\begin{tabular}{|c|c|c|c|c|c|c|c|c|c|c|c|c|}
\hline \multirow{2}{*}{$\begin{array}{l}\text { Dependent variable } \\
\text { Model }^{\mathrm{a}} \\
\end{array}$} & \multicolumn{4}{|c|}{$Y$} & \multicolumn{4}{|c|}{$V A / L$} & \multicolumn{4}{|c|}{ TFP } \\
\hline & [1] & [2] & [3] & [4] & [5] & [6] & [7] & [8] & [9] & [10] & [11] & [12] \\
\hline \multicolumn{13}{|l|}{ Spillover variable ${ }^{b}$} \\
\hline HORFDI2 & $\begin{array}{c}0.0159 \\
(0.015)\end{array}$ & & $\begin{array}{r}0.0168 \\
(0.015)\end{array}$ & & $\begin{array}{l}0.0920^{*} \\
(0.054)\end{array}$ & & $\begin{array}{l}0.0919^{*} \\
(0.054)\end{array}$ & & $\begin{array}{r}0.0235 \\
(0.014)\end{array}$ & & $\begin{array}{r}0.0230 \\
(0.014)\end{array}$ & \\
\hline HORFDI2N & & $\begin{array}{l}0.0236{ }^{*} \\
(0.013)\end{array}$ & & $\begin{array}{l}0.0239^{*} \\
(0.013)\end{array}$ & & $\begin{array}{l}0.0722 \\
(0.046)\end{array}$ & & $\begin{array}{l}0.0716 \\
(0.046)\end{array}$ & & $\begin{array}{l}0.0236^{*} \\
(0.012)\end{array}$ & & $\begin{array}{l}0.0230 * \\
(0.012)\end{array}$ \\
\hline HORFDI3N & & $\begin{array}{l}-0.0225{ }^{*} \\
(0.012)\end{array}$ & & $\begin{array}{l}-0.0215^{*} \\
(0.012)\end{array}$ & & $\begin{array}{l}-0.0222 \\
(0.043)\end{array}$ & & $\begin{array}{l}-0.0219 \\
(0.044)\end{array}$ & & $\begin{array}{c}-0.0194 * \\
(0.012)\end{array}$ & & $\begin{array}{l}-0.0197^{*} \\
(0.012)\end{array}$ \\
\hline HORFDI4 & & $\begin{array}{l}0.0215 \\
(0.011)\end{array}$ & & $\begin{array}{l}0.0218 \\
(0.011)\end{array}$ & & $\begin{array}{l}0.07311^{* * *} \\
(0.037)\end{array}$ & & $\begin{array}{l}0.0732 \\
(0.037)\end{array}$ & & $\begin{array}{l}0.0266 \\
(0.010)\end{array}$ & & $\begin{array}{l}0.0265 \text { **t } \\
(0.010)\end{array}$ \\
\hline BACFDI2 & $\begin{array}{l}0.0053 \\
(0.029)\end{array}$ & $\begin{array}{l}0.0091 \\
(0.029)\end{array}$ & & & $\begin{array}{l}0.0125 \\
(0.102)\end{array}$ & $\begin{array}{l}0.0196 \\
(0.103)\end{array}$ & & & $\begin{array}{l}0.0072 \\
(0.027)\end{array}$ & $\begin{array}{l}0.0103 \\
(0.027)\end{array}$ & & \\
\hline FORFDI2 & & & $\begin{array}{r}-0.0242 \\
(0.033)\end{array}$ & $\begin{array}{r}-0.0225 \\
(0.033)\end{array}$ & & & $\begin{array}{r}-0.0021 \\
(0.117)\end{array}$ & $\begin{array}{r}-0.0008 \\
(0.118)\end{array}$ & & & $\begin{array}{l}0.0089 \\
(0.031)\end{array}$ & $\begin{array}{l}0.0108 \\
(0.031)\end{array}$ \\
\hline \multicolumn{13}{|l|}{ Input variable } \\
\hline K & $\begin{array}{l}0.1328 \text { *** } \\
(0.004)\end{array}$ & $\begin{array}{l}0.1326^{* * * *} \\
(0.004)\end{array}$ & $\begin{array}{l}0.1328 \\
(0.004)\end{array}$ & $\begin{array}{l}0.1326 \\
(0.004)\end{array}$ & & & & & & & & \\
\hline$L$ & $\begin{array}{l}0.1525^{* * *} \\
(0.004)\end{array}$ & $\begin{array}{l}0.1526^{* * *} \\
(0.004)\end{array}$ & $\begin{array}{l}0.1525^{* * *} \\
(0.004)\end{array}$ & $\begin{array}{l}0.1526^{* * *} \\
(0.004)\end{array}$ & & & & & & & & \\
\hline$M$ & $\begin{array}{l}0.7014 \\
(0.003)\end{array}$ & $\begin{array}{l}0.7014^{* * * *} \\
(0.003)\end{array}$ & $\begin{array}{l}0.7013^{* * *} \\
(0.003)\end{array}$ & $\begin{array}{l}0.7014 \\
(0.003)\end{array}$ & & & & & & & & \\
\hline$K / L$ & & & & & $\begin{array}{l}0.4770 \\
(0.011)\end{array}$ & $\begin{array}{l}0.4767 \\
(0.011)\end{array}$ & $\begin{array}{l}0.4770 \\
(0.011)\end{array}$ & $\begin{array}{l}0.4767^{* * *} \\
(0.011)\end{array}$ & & & & \\
\hline \multicolumn{13}{|l|}{ Control variable } \\
\hline$F S^{b}$ & $\begin{array}{l}0.0399^{* * * 4} \\
(0.015)\end{array}$ & $\begin{array}{l}0.0399 \text { *** } \\
(0.015)\end{array}$ & $\begin{array}{l}0.0400 \\
(0.015)\end{array}$ & $\begin{array}{l}0.0401 \\
(0.015)\end{array}$ & $\begin{array}{l}0.12922^{* *} \\
(0.052)\end{array}$ & $\begin{array}{l}0.1290^{* *} \\
(0.052)\end{array}$ & $\begin{array}{l}0.12922^{* *} \\
(0.052)\end{array}$ & $\begin{array}{l}0.1290^{* *} \\
(0.052)\end{array}$ & $\begin{array}{l}0.02822^{* *} \\
(0.014)\end{array}$ & $\begin{array}{l}0.02822^{* *} \\
(0.014)\end{array}$ & $\begin{array}{l}0.0281^{* *} \\
(0.014)\end{array}$ & $\begin{array}{l}0.02822^{* *} \\
(0.014)\end{array}$ \\
\hline$G S^{b}$ & $\begin{array}{l}0.0145 \\
(0.022)\end{array}$ & $\begin{array}{l}0.0131 \\
(0.022)\end{array}$ & $\begin{array}{c}0.0145 \\
(0.022)\end{array}$ & $\begin{array}{l}0.0132 \\
(0.022)\end{array}$ & $\begin{array}{l}0.0452 \\
(0.078)\end{array}$ & $\begin{array}{l}0.0423 \\
(0.078)\end{array}$ & $\begin{array}{l}0.0452 \\
(0.078)\end{array}$ & $\begin{array}{l}0.0423 \\
(0.078)\end{array}$ & $\begin{array}{c}-0.0001 \\
(0.021)\end{array}$ & $\begin{array}{r}-0.0015 \\
(0.021)\end{array}$ & $\begin{array}{l}-0.0001 \\
(0.021)\end{array}$ & $\begin{array}{r}-0.0015 \\
(0.021)\end{array}$ \\
\hline$E X P P R O^{D}$ & $\begin{array}{r}-0.0098 \\
(0.017)\end{array}$ & $\begin{array}{r}-0.0165 \\
(0.017)\end{array}$ & $\begin{array}{r}-0.0105 \\
(0.017)\end{array}$ & $\begin{array}{r}-0.0172 \\
(0.017)\end{array}$ & $\begin{array}{l}0.0281 \\
(0.060)\end{array}$ & $\begin{array}{l}0.0131 \\
(0.060)\end{array}$ & $\begin{array}{l}0.0279 \\
(0.060)\end{array}$ & $\begin{array}{l}0.0128 \\
(0.060)\end{array}$ & $\begin{array}{r}-0.0129 \\
(0.016)\end{array}$ & $\begin{array}{r}-0.0195 \\
(0.016)\end{array}$ & $\begin{array}{r}-0.0128 \\
(0.016)\end{array}$ & $\begin{array}{r}-0.0194 \\
(0.016)\end{array}$ \\
\hline HHI & $\begin{array}{l}-0.0120 \\
(0.011)\end{array}$ & $\begin{array}{l}-0.0121 \\
(0.011)\end{array}$ & $\begin{array}{r}-0.0119 \\
(0.011)\end{array}$ & $\begin{array}{r}-0.0121 \\
(0.011)\end{array}$ & $\begin{array}{r}-0.0282 \\
(0.038)\end{array}$ & $\begin{array}{r}-0.0284 \\
(0.038)\end{array}$ & $\begin{array}{r}-0.0282 \\
(0.038)\end{array}$ & $\begin{array}{l}-0.0283 \\
(0.038)\end{array}$ & $\begin{array}{c}-0.0132 \\
(0.010)\end{array}$ & $\begin{array}{c}-0.0134 \\
(0.010)\end{array}$ & $\begin{array}{l}-0.0133 \\
(0.010)\end{array}$ & $\begin{array}{l}-0.0134 \\
(0.010)\end{array}$ \\
\hline Const. & $\begin{array}{l}1.8484^{* * *} \\
(0.047)\end{array}$ & $\begin{array}{l}1.84355^{* * *} \\
(0.047)\end{array}$ & $\begin{array}{l}1.86099^{* * *} \\
(0.048)\end{array}$ & $\begin{array}{l}1.8568 \\
(0.048)\end{array}$ & $\begin{array}{l}3.4707^{* * *} \\
(0.105)\end{array}$ & $\begin{array}{l}3.45955^{* * *} \\
(0.105)\end{array}$ & $\begin{array}{l}3.4772 \\
(0.105)\end{array}$ & $\begin{array}{l}3.4688^{* * *} \\
(0.105)\end{array}$ & $\begin{array}{r}-0.0090 \\
(0.014)\end{array}$ & $\begin{array}{r}-0.0136 \\
(0.015)\end{array}$ & $\begin{array}{r}-0.0093 \\
(0.015)\end{array}$ & $\begin{array}{r}-0.0132 \\
(0.015)\end{array}$ \\
\hline Location fixed-effects & Yes & Yes & Yes & Yes & Yes & Yes & Yes & Yes & Yes & Yes & Yes & Yes \\
\hline Year fixed-effects & Yes & Yes & Yes & Yes & Yes & Yes & Yes & Yes & Yes & Yes & Yes & Yes \\
\hline Firm fixed-effects & Yes & Yes & Yes & Yes & Yes & Yes & Yes & Yes & Yes & Yes & Yes & Yes \\
\hline $\mathrm{N}$ & 22677 & 22677 & 22677 & 22677 & 22716 & 22716 & 22716 & 22716 & 22677 & 22677 & 22677 & 22677 \\
\hline $\mathrm{R}^{2}$ & 0.973 & 0.973 & 0.973 & 0.973 & 0.382 & 0.383 & 0.382 & 0.383 & 0.007 & 0.009 & 0.009 & 0.011 \\
\hline$F$ test $^{\mathrm{c}}$ & $6122.89^{9 * * *}$ & $5310.22^{* * * *}$ & $6123.14^{* * * *}$ & $5310.37^{* * * *}$ & $187.90^{* * * *}$ & $159.36^{* * *}$ & $187.90^{* * * *}$ & $159.35^{* * *}$ & $12.51^{* * * *}$ & $11.44^{* * * *}$ & $12.51^{* * * *}$ & 11.44 \\
\hline Breusch-Pagan test ${ }^{\mathrm{d}}$ & $11272.366^{* * *}$ & $11254.11^{* * *}$ & $11203.96^{* * * *}$ & $11179.24 * * *$ & $7436.66^{* * * *}$ & $7420.40^{* * * *}$ & $7285.83^{* * * *}$ & $7266.89^{* * *}$ & $10751.300^{* * *}$ & $10742.74^{* * * *}$ & $10618.21 * * *$ & $10606.77^{* * *}$ \\
\hline Hausman test ${ }^{e}$ & $178.88^{* * *}$ & $189.26^{* * *}$ & $195.25^{* * *}$ & $221.99^{* * *}$ & $63.22^{* * *}$ & $67.94^{* * * *}$ & $65.23^{* * * *}$ & $75.67^{* * * *}$ & $95.18^{* * *}$ & $90.56^{* * *}$ & $91.63^{* * *}$ & 98.38 *** \\
\hline
\end{tabular}


Table 5 (continued)

\begin{tabular}{|c|c|c|c|c|c|c|c|c|c|c|c|c|}
\hline \multirow{2}{*}{$\begin{array}{l}\text { Dependent variable } \\
\text { Model }^{\mathrm{a}} \\
\end{array}$} & \multicolumn{4}{|c|}{ Y } & \multicolumn{4}{|c|}{$V A / L$} & \multicolumn{4}{|c|}{ TFP } \\
\hline & [13] & [14] & [15] & [16] & [17] & [18] & [19] & [20] & [21] & [22] & [23] & [24] \\
\hline \multicolumn{13}{|l|}{ Spillover variable ${ }^{\mathrm{b}}$} \\
\hline HORFDI2 & $\begin{array}{l}-0.03911^{* *} \\
(0.020)\end{array}$ & & $\begin{array}{l}-0.0355 * \\
(0.020)\end{array}$ & & $\begin{array}{l}-0.0683 \\
(0.074)\end{array}$ & & $\begin{array}{l}-0.0676 \\
(0.074)\end{array}$ & & $\begin{array}{l}-0.04122^{* *} \\
(0.018)\end{array}$ & & $\begin{array}{l}-0.03755^{* *} \\
(0.018)\end{array}$ & \\
\hline HORFDI2N & & $\begin{array}{l}-0.02511^{*} \\
(0.015)\end{array}$ & & $\begin{array}{l}-0.0225 \\
(0.015)\end{array}$ & & $\begin{array}{l}0.0037 \\
(0.055)\end{array}$ & & $\begin{array}{l}0.0062 \\
(0.055)\end{array}$ & & $\begin{array}{l}-0.0178 \\
(0.013)\end{array}$ & & $\begin{array}{r}-0.0149 \\
(0.013)\end{array}$ \\
\hline HORFDI3N & & $\begin{array}{l}0.0046 \\
(0.008)\end{array}$ & & $\begin{array}{l}0.0069 \\
(0.008)\end{array}$ & & $\begin{array}{l}0.0486 * \\
(0.029)\end{array}$ & & $\begin{array}{l}0.0535^{*} \\
(0.031)\end{array}$ & & $\begin{array}{r}-0.0072 \\
(0.008)\end{array}$ & & $\begin{array}{r}-0.0046 \\
(0.008)\end{array}$ \\
\hline HORFDI4 & & $\begin{array}{r}-0.0062 \\
(0.009)\end{array}$ & & $\begin{array}{r}-0.0064 \\
(0.009)\end{array}$ & & $\begin{array}{l}-0.0154 \\
(0.034)\end{array}$ & & $\begin{array}{r}-0.0194 \\
(0.034)\end{array}$ & & $\begin{array}{r}-0.0117 \\
(0.008)\end{array}$ & & $\begin{array}{r}-0.0122 \\
(0.008)\end{array}$ \\
\hline BACFDI2 & $\begin{array}{l}-0.09399^{* *} \\
(0.046)\end{array}$ & $\begin{array}{l}-0.0885^{*} \\
(0.046)\end{array}$ & & & $\begin{array}{l}-0.1892 \\
(0.172)\end{array}$ & $\begin{array}{l}-0.1367 \\
(0.175)\end{array}$ & & & $\begin{array}{l}-0.0989^{* * *} \\
(0.042)\end{array}$ & $\begin{array}{l}-0.10022^{* *} \\
(0.042)\end{array}$ & & \\
\hline FORFDI2 & & & $\begin{array}{l}-0.0436 \\
(0.039)\end{array}$ & $\begin{array}{l}-0.0434 \\
(0.039)\end{array}$ & & & $\begin{array}{l}0.1186 \\
(0.147)\end{array}$ & $\begin{array}{c}0.1226 \\
(0.147)\end{array}$ & & & $\begin{array}{l}-0.0415 \\
(0.036)\end{array}$ & $\begin{array}{l}-0.0417 \\
(0.036)\end{array}$ \\
\hline \multicolumn{13}{|l|}{ Input variable } \\
\hline$K$ & $\begin{array}{l}0.1064 \\
(0.002)\end{array}$ & $\begin{array}{l}0.1064^{* * * *} \\
(0.002)\end{array}$ & $\begin{array}{l}0.1064^{* * *} \\
(0.002)\end{array}$ & $\begin{array}{l}0.1064^{* * * *} \\
(0.002)\end{array}$ & & & & & & & & \\
\hline$L$ & $\begin{array}{l}0.1399^{* * *} \\
(0.003)\end{array}$ & $\begin{array}{l}0.1399^{* * *} \\
(0.003)\end{array}$ & $\begin{array}{l}0.1400^{* * *} \\
(0.003)\end{array}$ & $\begin{array}{l}0.1400^{* * *} \\
(0.003)\end{array}$ & & & & & & & & \\
\hline M & $\begin{array}{l}0.7339^{\text {*** }} \\
(0.002)\end{array}$ & $\begin{array}{l}0.7338^{* * * *} \\
(0.002)\end{array}$ & $\begin{array}{l}0.7338^{* * *} \\
(0.002)\end{array}$ & $\begin{array}{l}0.7337^{* * *} \\
(0.002)\end{array}$ & & & & & & & & \\
\hline$K / L$ & & & & & $\begin{array}{l}0.44400^{* * *} \\
(0.007)\end{array}$ & $\begin{array}{l}0.44400^{* * *} \\
(0.007)\end{array}$ & $\begin{array}{l}0.44388^{* * *} \\
(0.007)\end{array}$ & $\begin{array}{l}0.4439^{* * *} \\
(0.007)\end{array}$ & & & & \\
\hline \multicolumn{13}{|l|}{ Control variable } \\
\hline$F S^{b}$ & $\begin{array}{l}0.0206^{*} \\
(0.012)\end{array}$ & $\begin{array}{l}0.0208^{*} \\
(0.012)\end{array}$ & $\begin{array}{l}0.0207^{*} \\
(0.012)\end{array}$ & $\begin{array}{l}0.0209^{*} \\
(0.012)\end{array}$ & $\begin{array}{l}0.0553 \\
(0.045)\end{array}$ & $\begin{array}{l}0.0565 \\
(0.045)\end{array}$ & $\begin{array}{l}0.0551 \\
(0.045)\end{array}$ & $\begin{array}{l}0.0564 \\
(0.045)\end{array}$ & $\begin{array}{l}0.0170 \\
(0.011)\end{array}$ & $\begin{array}{l}0.0168 \\
(0.011)\end{array}$ & $\begin{array}{l}0.0171 \\
(0.011)\end{array}$ & $\begin{array}{l}0.0170 \\
(0.011)\end{array}$ \\
\hline$G S^{b}$ & $\begin{array}{c}-0.0169 \\
(0.015)\end{array}$ & $\begin{array}{r}-0.0172 \\
(0.015)\end{array}$ & $\begin{array}{l}-0.0167 \\
(0.015)\end{array}$ & $\begin{array}{c}-0.0171 \\
(0.015)\end{array}$ & $\begin{array}{l}0.0692 \\
(0.057)\end{array}$ & $\begin{array}{l}0.0677 \\
(0.057)\end{array}$ & $\begin{array}{l}0.0696 \\
(0.057)\end{array}$ & $\begin{array}{l}0.0679 \\
(0.057)\end{array}$ & $\begin{array}{r}-0.0034 \\
(0.014)\end{array}$ & $\begin{array}{c}-0.0033 \\
(0.014)\end{array}$ & $\begin{array}{r}-0.0032 \\
(0.014)\end{array}$ & $\begin{array}{r}-0.0032 \\
(0.014)\end{array}$ \\
\hline$E X P P R O^{D}$ & $\begin{array}{l}-0.0309 \\
(0.022)\end{array}$ & $\begin{array}{l}-0.0296 \\
(0.023)\end{array}$ & $\begin{array}{l}-0.0291 \\
(0.022)\end{array}$ & $\begin{array}{l}-0.0274 \\
(0.023)\end{array}$ & $\begin{array}{l}0.0916 \\
(0.084)\end{array}$ & $\begin{array}{l}0.1034 \\
(0.085)\end{array}$ & $\begin{array}{l}0.0914 \\
(0.084)\end{array}$ & $\begin{array}{l}0.1046 \\
(0.085)\end{array}$ & $\begin{array}{r}-0.0027 \\
(0.020)\end{array}$ & $\begin{array}{r}-0.0018 \\
(0.021)\end{array}$ & $\begin{array}{r}-0.0010 \\
(0.020)\end{array}$ & $\begin{array}{l}0.0007 \\
(0.021)\end{array}$ \\
\hline HHI & $\begin{array}{l}0.0040 \\
(0.009)\end{array}$ & $\begin{array}{l}0.0039 \\
(0.009)\end{array}$ & $\begin{array}{l}0.0047 \\
(0.009)\end{array}$ & $\begin{array}{l}0.0046 \\
(0.009)\end{array}$ & $\begin{array}{l}0.0516 \\
(0.035)\end{array}$ & $\begin{array}{l}0.0516 \\
(0.035)\end{array}$ & $\begin{array}{l}0.0532 \\
(0.035)\end{array}$ & $\begin{array}{l}0.0527 \\
(0.035)\end{array}$ & $\begin{array}{r}-0.0035 \\
(0.008)\end{array}$ & $\begin{array}{r}-0.0036 \\
(0.008)\end{array}$ & $\begin{array}{r}-0.0028 \\
(0.008)\end{array}$ & $\begin{array}{l}-0.0028 \\
(0.008)\end{array}$ \\
\hline Const. & $\begin{array}{l}1.9094^{* * *} \\
(0.033)\end{array}$ & $\begin{array}{l}1.9032 \\
(0.034)\end{array}$ & $\begin{array}{l}1.8869^{* * *} \\
(0.031)\end{array}$ & $\begin{array}{l}1.8828 \\
(0.031)\end{array}$ & $\begin{array}{l}3.89966^{* * *} \\
(0.096)\end{array}$ & $\begin{array}{l}3.84766^{* * *} \\
(0.096)\end{array}$ & $\begin{array}{l}3.7836 \\
(0.083)\end{array}$ & $\begin{array}{l}3.7502 \\
(0.082)\end{array}$ & $\begin{array}{l}0.0594 \\
(0.018)\end{array}$ & $\begin{array}{l}0.0560 \\
(0.018)\end{array}$ & $\begin{array}{l}0.03355^{* *} \\
(0.014)\end{array}$ & $\begin{array}{l}0.0295 \text { *** } \\
(0.014)\end{array}$ \\
\hline Location fixed-effects & Yes & Yes & Yes & Yes & Yes & Yes & Yes & Yes & Yes & Yes & Yes & Yes \\
\hline Year fixed-effects & Yes & Yes & Yes & Yes & Yes & Yes & Yes & Yes & Yes & Yes & Yes & Yes \\
\hline Firm fixed-effects & Yes & Yes & Yes & Yes & Yes & Yes & Yes & Yes & Yes & Yes & Yes & Yes \\
\hline $\mathrm{N}$ & 48690 & 48690 & 48690 & 48690 & 48585 & 48585 & 48585 & 48585 & 48690 & 48690 & 48690 & 48690 \\
\hline $\mathrm{R}^{2}$ & 0.967 & 0.967 & 0.967 & 0.967 & 0.398 & 0.398 & 0.401 & 0.401 & 0.001 & 0.001 & 0.001 & 0.001 \\
\hline$F$ test $^{c}$ & 17001.55 **** & $14733.73^{* * *}$ & $16999.75 * * * *$ & $14732.47^{* * * *}$ & $376.82^{* * * *}$ & $318.96^{* * * *}$ & 376.76 **** & $318.97^{* * * *}$ & $27.94 * * * *$ & $23.23^{* * *}$ & $27.51 * * * *$ & $22.88^{* * * *}$ \\
\hline Breusch-Pagan test $^{\mathrm{d}}$ & $29844.06{ }^{* * * *}$ & $29456.88^{* * * *}$ & $29393.10{ }^{* * * *}$ & $29157.38^{* * * *}$ & $17620.28{ }^{* * * *}$ & $17016.20^{* * * *}$ & $17112.15^{* * * *}$ & $16557.33^{* * * *}$ & $26671.95^{* * * *}$ & $26189.33^{* * *}$ & $25858.19^{* * * *}$ & $25510.96 * * *$ \\
\hline Hausman test $^{\mathrm{e}}$ & $599.80^{* * *}$ & $730.86^{* * *}$ & $717.54^{* * *}$ & $794.54^{* * *}$ & $117.05^{* * * *}$ & $620.01^{* * * *}$ & $228.17^{* * *}$ & $828.29^{* * * *}$ & $172.25^{* * * *}$ & $330.39^{* * * *}$ & $386.16^{* * *}$ & $483.66^{* * * *}$ \\
\hline
\end{tabular}


Figure 2. Likely relationship between MNEs and domestic companies in the Hungarian manufacturing sector from the viewpoint of productivity spillover effects of horizontal FDI

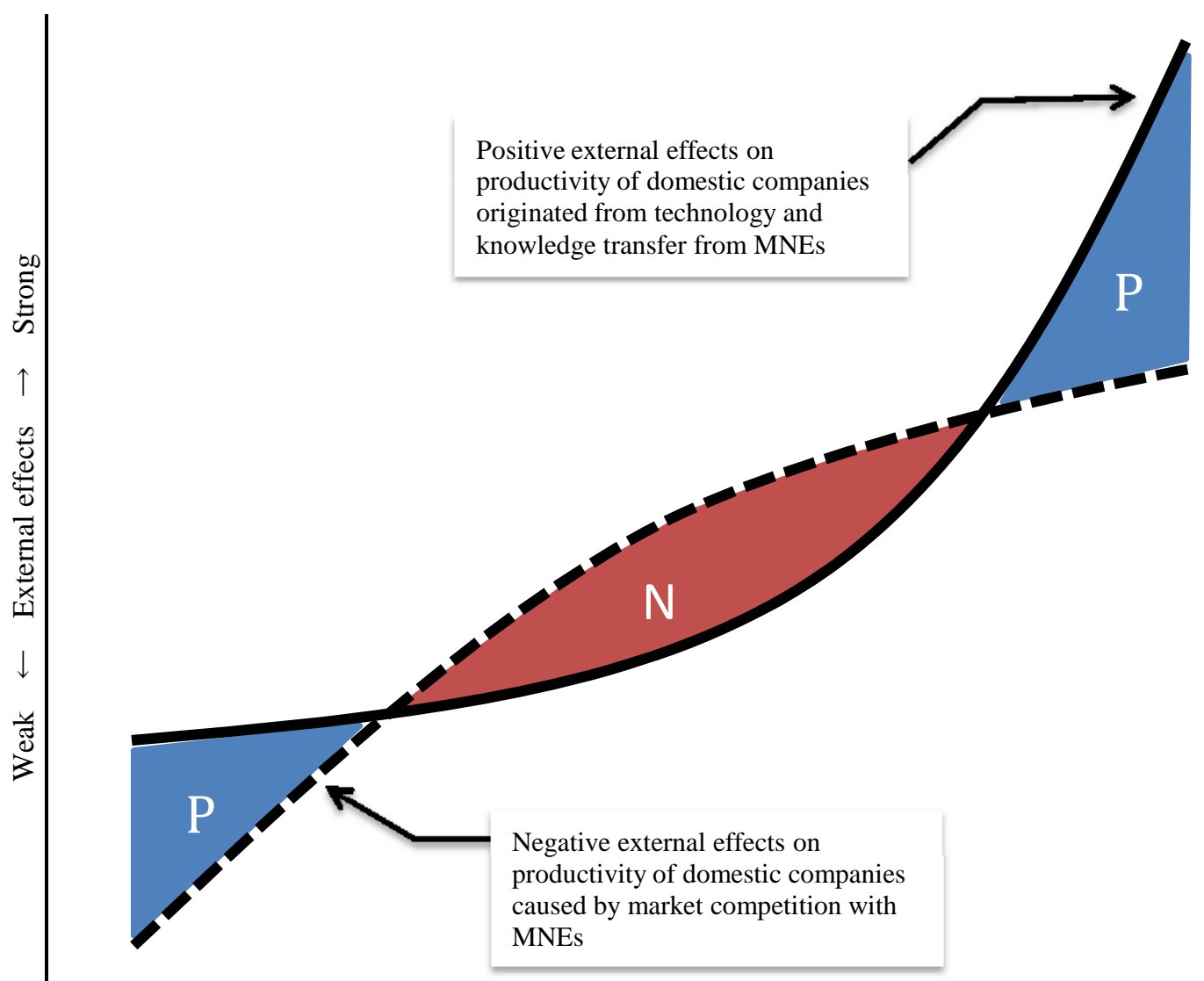

Far $\leftarrow$ Industrial-technological proximity $\rightarrow$ Close

Source: Authors' illustration. See text for details. 
Table 6. Estimation results by differentiating observations between fully domestically owned firms and foreign joint-venture firms

(a) Fully domestically owned firms

\begin{tabular}{|c|c|c|c|c|c|c|}
\hline \multirow{2}{*}{$\begin{array}{l}\text { Industrial sector } \\
\text { Dependent variable }\end{array}$} & \multicolumn{3}{|c|}{ Manufacturing } & \multicolumn{3}{|c|}{ Services } \\
\hline & $Y$ & $V A / L$ & TFP & $\bar{Y}$ & $V A / L$ & TFP \\
\hline HORFDI2N & $\begin{array}{l}0.0244^{*} \\
(0.014)\end{array}$ & $\begin{array}{l}0.0632 \\
(0.050)\end{array}$ & $\begin{array}{l}0.0226^{*} \\
(0.013)\end{array}$ & $\begin{array}{l}-0.0282^{*} \\
(0.015)\end{array}$ & $\begin{array}{r}-0.0083 \\
(0.056)\end{array}$ & $\begin{array}{r}-0.0191 \\
(0.014)\end{array}$ \\
\hline HORFDI3N & $\begin{array}{c}-0.0273^{* *} \\
(0.013)\end{array}$ & $\begin{array}{r}-0.0146 \\
(0.046)\end{array}$ & $\begin{array}{l}-0.02177^{*} \\
(0.012)\end{array}$ & $\begin{array}{l}0.0079 \\
(0.009)\end{array}$ & $\begin{array}{c}0.0631 \\
(0.033)\end{array}$ & $\begin{array}{r}-0.0058 \\
(0.008)\end{array}$ \\
\hline HORFDI4 & $\begin{array}{l}0.0270 \\
(0.011)\end{array}$ & $\begin{array}{l}0.0654 \\
(0.038)\end{array}$ & $\begin{array}{l}0.0312^{* * *} \\
(0.011)\end{array}$ & $\begin{array}{r}-0.0080 \\
(0.009)\end{array}$ & $\begin{array}{r}-0.0166 \\
(0.035)\end{array}$ & $\begin{array}{r}-0.0117 \\
(0.008)\end{array}$ \\
\hline BACFDI2 & $\begin{array}{r}0.0098 \\
(0.030) \\
\end{array}$ & $\begin{array}{r}0.0122 \\
(0.109)\end{array}$ & $\begin{array}{r}0.0105 \\
(0.029) \\
\end{array}$ & $\begin{array}{c}-0.0938 \text { * } \\
(0.049)\end{array}$ & $\begin{array}{r}-0.1336 \\
(0.183) \\
\end{array}$ & $\begin{array}{l}-0.0975^{* *} \\
(0.044)\end{array}$ \\
\hline $\mathrm{N}$ & 20902 & 20906 & 20902 & 46357 & 46254 & 46357 \\
\hline $\mathrm{R}^{2}$ & 0.972 & 0.363 & 0.007 & 0.966 & 0.391 & 0.001 \\
\hline \multicolumn{7}{|c|}{ (b) Foreign joint-venture firms } \\
\hline Industrial sector & \multicolumn{3}{|c|}{ Manufacturing } & \multicolumn{3}{|c|}{ Services } \\
\hline Dependent variable & $Y$ & $V A / L$ & TFP & $Y$ & $V A / L$ & TFP \\
\hline HORFDI2N & $\begin{array}{l}0.0682 \\
(0.044)\end{array}$ & $\begin{array}{l}0.2304^{* *} \\
(0.113)\end{array}$ & $\begin{array}{l}0.0711^{*} \\
(0.037)\end{array}$ & $\begin{array}{r}-0.0181 \\
(0.067)\end{array}$ & $\begin{array}{l}0.1447 \\
(0.299)\end{array}$ & $\begin{array}{l}0.0029 \\
(0.062)\end{array}$ \\
\hline HORFDI3N & $\begin{array}{r}0.0045 \\
(0.041)\end{array}$ & $\begin{array}{r}-0.0458 \\
(0.105)\end{array}$ & $\begin{array}{r}-0.0128 \\
(0.035)\end{array}$ & $\begin{array}{r}-0.0166 \\
(0.032)\end{array}$ & $\begin{array}{r}-0.0248 \\
(0.135)\end{array}$ & $\begin{array}{r}-0.0273 \\
(0.030)\end{array}$ \\
\hline HORFDI4 & $\begin{array}{r}-0.0046 \\
(0.036)\end{array}$ & $\begin{array}{r}0.0978 \\
(0.090)\end{array}$ & $\begin{array}{r}-0.0053 \\
(0.031)\end{array}$ & $\begin{array}{r}-0.0112 \\
(0.041)\end{array}$ & $\begin{array}{r}0.0463 \\
(0.171)\end{array}$ & $\begin{array}{r}-0.0372 \\
(0.038)\end{array}$ \\
\hline BACFDI2 & $\begin{array}{r}-0.1418 \\
(0.111)\end{array}$ & $\begin{array}{r}-0.0785 \\
(0.285)\end{array}$ & $\begin{array}{r}-0.0105 \\
(0.095)\end{array}$ & $\begin{array}{r}-0.0435 \\
(0.165)\end{array}$ & $\begin{array}{r}0.2991 \\
(0.701)\end{array}$ & $\begin{array}{r}-0.1049 \\
(0.155)\end{array}$ \\
\hline $\mathrm{N}$ & 1775 & 1810 & 1775 & 2333 & 2331 & 2333 \\
\hline $\mathrm{R}^{2}$ & 0.972 & 0.446 & 0.001 & 0.971 & 0.365 & 0.003 \\
\hline
\end{tabular}

the coefficient estimates of other independent variables are not reported here. All specifications include a constant and

location, year, and firm fixed-effects. The Huber-White heteroskedasticity-consistent standard errors are reported in

parentheses beneath the regression coefficients. $* * *, * *$, and $*$ denote statistical significance at the $1 \%, 5 \%$, and $10 \%$ level,

Source: Authors' estimation. For definitions and descriptive statistics of the variables, see Appendix. 
Table 7. Estimation results of FDI spillover variables computed using total turnover, total addedvalue, total equity capital, and annual average number of employees

(a) Total turnover

\begin{tabular}{|c|c|c|c|c|c|c|}
\hline Industrial sector & \multicolumn{3}{|c|}{ Manufacturing } & \multicolumn{3}{|c|}{ Services } \\
\hline Dependent variable & $Y$ & $V A / L$ & TFP & $Y$ & $V A / L$ & TFP \\
\hline HORFDI2TN & $\begin{array}{l}0.0274^{* *} \\
(0.013)\end{array}$ & $\begin{array}{l}0.0640 \\
(0.046)\end{array}$ & $\begin{array}{l}0_{0.0254^{* *}} \\
(0.012)\end{array}$ & $\begin{array}{l}-0.0332^{* *} \\
(0.015)\end{array}$ & $\begin{array}{l}-0.0848 \\
(0.057)\end{array}$ & $\begin{array}{l}-0.0309^{* *} \\
(0.014)\end{array}$ \\
\hline HORFDI3TN & $\begin{array}{r}-0.0200 \\
(0.012)\end{array}$ & $\begin{array}{r}-0.0150 \\
(0.043)\end{array}$ & $\begin{array}{c}-0.0176 \\
(0.012)\end{array}$ & $\begin{array}{r}0.0047 \\
(0.009)\end{array}$ & $\begin{array}{l}0.06811^{* *} \\
(0.035)\end{array}$ & $\begin{array}{l}-0.0047 \\
(0.009)\end{array}$ \\
\hline HORFDI4T & $\begin{array}{l}0.0082 \\
(0.011)\end{array}$ & $\begin{array}{l}0.0603 \\
(0.036)\end{array}$ & $\begin{array}{l}0.0156 \\
(0.009)\end{array}$ & $\begin{array}{l}0.0043 \\
(0.010)\end{array}$ & $\begin{array}{r}-0.0178 \\
(0.038)\end{array}$ & $\begin{array}{l}0.0012 \\
(0.009)\end{array}$ \\
\hline BACFDI2T & $\begin{array}{r}-0.0079 \\
(0.028) \\
\end{array}$ & $\begin{array}{r}-0.0438 \\
(0.100) \\
\end{array}$ & $\begin{array}{r}-0.0086 \\
(0.027) \\
\end{array}$ & $\begin{array}{r}-0.0426 \\
(0.041) \\
\end{array}$ & $\begin{array}{r}0.0393 \\
(0.156) \\
\end{array}$ & $\begin{array}{l}-0.0725^{*} \\
(0.038) \\
\end{array}$ \\
\hline $\mathrm{N}$ & 22677 & 22716 & 22677 & 48690 & 48585 & 48690 \\
\hline$R^{2}$ & 0.973 & 0.381 & 0.006 & 0.967 & 0.400 & 0.001 \\
\hline
\end{tabular}

(b) Total added-value

\begin{tabular}{|c|c|c|c|c|c|c|}
\hline Industrial sector & \multicolumn{3}{|c|}{ Manufacturing } & \multicolumn{3}{|c|}{ Services } \\
\hline Dependent variable & $Y$ & $V A / L$ & TFP & $Y$ & $V A / L$ & TFP \\
\hline HORFDI2VN & $\begin{array}{l}0^{0.0294^{* *}} \\
(0.012)\end{array}$ & $\begin{array}{l}0.0531 \\
(0.042)\end{array}$ & $\begin{array}{l}0_{0.0264^{* *}} \\
(0.011)\end{array}$ & $\begin{array}{l}0.0084 \\
(0.013)\end{array}$ & $\begin{array}{c}0.0582 \\
(0.050)\end{array}$ & $\begin{array}{l}-0.0033 \\
(0.012)\end{array}$ \\
\hline HORFDI3VN & $\begin{array}{l}-0.0280 \\
(0.009)\end{array}$ & $\begin{array}{l}-0.0668 \\
(0.032)\end{array}$ & $\begin{array}{l}-0.0235^{* * *} \\
(0.009)\end{array}$ & $\begin{array}{l}0.0087 \\
(0.008)\end{array}$ & $\begin{array}{l}0.0675^{* *} \\
(0.028)\end{array}$ & $\begin{array}{r}0.0018 \\
(0.007)\end{array}$ \\
\hline HORFDI4V & $\begin{array}{r}-0.0052 \\
(0.009)\end{array}$ & $\begin{array}{r}-0.0111 \\
(0.031)\end{array}$ & $\begin{array}{r}-0.0007 \\
(0.008)\end{array}$ & $\begin{array}{r}0.0040 \\
(0.009)\end{array}$ & $\begin{array}{l}-0.0083 \\
(0.032)\end{array}$ & $\begin{array}{r}-0.0059 \\
(0.008)\end{array}$ \\
\hline BACFDI2V & $\begin{array}{r}0.0203 \\
(0.028) \\
\end{array}$ & $\begin{array}{r}0.0516 \\
(0.100)\end{array}$ & $\begin{array}{r}0.0130 \\
(0.027) \\
\end{array}$ & $\begin{array}{r}-0.0405 \\
(0.045) \\
\end{array}$ & $\begin{array}{r}0.0547 \\
(0.169) \\
\end{array}$ & $\begin{array}{r}-0.0645 \\
(0.041)\end{array}$ \\
\hline $\mathrm{N}$ & 22677 & 22716 & 22677 & 48690 & 48585 & 48690 \\
\hline$R^{2}$ & 0.973 & 0.382 & 0.005 & 0.967 & 0.398 & 0.001 \\
\hline
\end{tabular}

(c) Total equity capital

\begin{tabular}{|c|c|c|c|c|c|c|}
\hline Industrial sector & \multicolumn{3}{|c|}{ Manufacturing } & \multicolumn{3}{|c|}{ Services } \\
\hline Dependent variable & $Y$ & $V A / L$ & TFP & $Y$ & $V A / L$ & TFP \\
\hline HORFDI2EN & $\begin{array}{l}0.0206 \\
(0.013)\end{array}$ & $\begin{array}{l}0.0427 \\
(0.047)\end{array}$ & $\begin{array}{l}0.0170 \\
(0.013)\end{array}$ & $\begin{array}{l}-0.0265^{* *} \\
(0.011)\end{array}$ & $\begin{array}{r}-0.0670 \\
(0.042)\end{array}$ & $\begin{array}{l}-0.0233^{* *} \\
(0.010)\end{array}$ \\
\hline HORFDI3EN & $\begin{array}{r}-0.0116 \\
(0.011)\end{array}$ & $\begin{array}{r}-0.0333 \\
(0.039)\end{array}$ & $\begin{array}{r}-0.0094 \\
(0.010)\end{array}$ & $\begin{array}{r}-0.0025 \\
(0.008)\end{array}$ & $\begin{array}{r}-0.0155 \\
(0.031)\end{array}$ & $\begin{array}{r}-0.0080 \\
(0.007)\end{array}$ \\
\hline HORFDI4E & $\begin{array}{l}0.0280^{* * *} \\
(0.009)\end{array}$ & $\begin{array}{l}0.09177^{* * *} \\
(0.033)\end{array}$ & $\begin{array}{l}0.0266^{* * *} \\
(0.009)\end{array}$ & $\begin{array}{r}-0.0086 \\
(0.008)\end{array}$ & $\begin{array}{r}-0.0449 \\
(0.030)\end{array}$ & $\begin{array}{l}-0.01499^{* *} \\
(0.007)\end{array}$ \\
\hline BACFDI2E & $\begin{array}{r}-0.0503 \\
(0.031) \\
\end{array}$ & $\begin{array}{l}-0.23044^{* *} \\
(0.110)\end{array}$ & $\begin{array}{c}-0.0463{ }^{*} \\
(0.027) \\
\end{array}$ & $\begin{array}{l}-0.1048{ }^{* *} \\
(0.042) \\
\end{array}$ & $\begin{array}{r}-0.1881 \\
(0.157) \\
\end{array}$ & $\begin{array}{l}-0.1045^{* * *} \\
(0.038)\end{array}$ \\
\hline $\mathrm{N}$ & 22677 & 22716 & 22677 & 48690 & 48585 & 48690 \\
\hline$R^{2}$ & 0.973 & 0.377 & 0.001 & 0.967 & 0.402 & 0.007 \\
\hline
\end{tabular}

(d) Annual average number of employees

\begin{tabular}{|c|c|c|c|c|c|c|}
\hline Industrial sector & & Manufacturin & & & Services & \\
\hline Dependent variable & $Y$ & $V A / L$ & TFP & $Y$ & $V A / L$ & TFP \\
\hline HORFDI $2 W N$ & $\begin{array}{l}0.0179 \\
(0.018)\end{array}$ & $\begin{array}{l}0.0385 \\
(0.063)\end{array}$ & $\begin{array}{r}0.0136 \\
(0.017)\end{array}$ & $\begin{array}{l}0.0140 \\
(0.021)\end{array}$ & $\begin{array}{l}0.1596^{* *} \\
(0.078)\end{array}$ & $\begin{array}{r}-0.0048 \\
(0.019)\end{array}$ \\
\hline HORFDI3WN & $\begin{array}{l}-0.0267^{*} \\
(0.015)\end{array}$ & $\begin{array}{r}-0.0333 \\
(0.052)\end{array}$ & $\begin{array}{r}-0.0227 \\
(0.014)\end{array}$ & $\begin{array}{r}-0.0069 \\
(0.015)\end{array}$ & $\begin{array}{r}-0.0140 \\
(0.055)\end{array}$ & $\begin{array}{r}-0.0107 \\
(0.014)\end{array}$ \\
\hline HORFDI4W & $\begin{array}{l}0.0308^{* *} \\
(0.014)\end{array}$ & $\begin{array}{l}0.0987^{* *} \\
(0.049)\end{array}$ & $\begin{array}{l}0.0325^{* *} \\
(0.013)\end{array}$ & $\begin{array}{r}0.0240 \\
(0.015)\end{array}$ & $\begin{array}{l}0.0007 \\
(0.055)\end{array}$ & $\begin{array}{l}0.0030 \\
(0.013)\end{array}$ \\
\hline BACFDI $2 W$ & $\begin{array}{r}-0.0101 \\
(0.037) \\
\end{array}$ & $\begin{array}{r}-0.0364 \\
(0.133) \\
\end{array}$ & $\begin{array}{r}-0.0187 \\
(0.035) \\
\end{array}$ & $\begin{array}{l}-0.1586^{* * *} \\
(0.048)\end{array}$ & $\begin{array}{l}-0.4843^{* * *} \\
(0.179)\end{array}$ & $\begin{array}{l}-0.1595^{* * *} \\
(0.043)\end{array}$ \\
\hline $\mathrm{N}$ & 22677 & 22716 & 22677 & 48690 & 48585 & 48690 \\
\hline$R^{2}$ & 0.973 & 0.382 & 0.006 & 0.967 & 0.393 & 0.001 \\
\hline
\end{tabular}




\begin{tabular}{|c|c|c|c|c|c|c|c|}
\hline \multirow{3}{*}{ Variable name } & \multirow{3}{*}{ Definition } & \multicolumn{6}{|c|}{ Descriptive statistics } \\
\hline & & \multicolumn{3}{|c|}{ Manufacturing } & \multicolumn{3}{|c|}{ Services } \\
\hline & & $\mathrm{N}$ & Mean & S. D. & $\mathrm{N}$ & Mean & S. D. \\
\hline \multicolumn{8}{|c|}{ Productivity variable (dependent variable) } \\
\hline Y & Annual total turnover (natural logarithm) & 22684 & 11.790 & 1.395 & 48719 & 11.927 & 1.365 \\
\hline$V A / L$ & Value-added per employee (natural logarithm) & 22722 & 7.566 & 0.799 & 48642 & 7.694 & 0.863 \\
\hline TFP & Total factor productivity (Levinsohn-Petrin semi-parametric estimation method) & 22677 & 0.012 & 0.203 & 48690 & 0.014 & 0.202 \\
\hline \multicolumn{8}{|l|}{ Spillover variable } \\
\hline HORFDI02 & Share of foreign capital in assets ownership in the industry the firm belongs to (NACE 2-digit level) & 22736 & 0.499 & 0.127 & 48782 & 0.356 & 0.128 \\
\hline HORFDIO2N & Share of foreign capital in assets ownership in the industry the firm belongs to (NACE 2-digit level: nested variable) & 22736 & 0.520 & 0.170 & 48782 & 0.345 & 0.154 \\
\hline HORFDIO3N & Share of foreign capital in assets ownership in the industry the firm belongs to (NACE 3-digit level: nested variable) & 22736 & 0.347 & 0.251 & 48782 & 0.203 & 0.223 \\
\hline HORFDI04 & Share of foreign capital in assets ownership in the industry the firm belongs to (NACE 4-digit level) & 22736 & 0.384 & 0.229 & 48782 & 0.265 & 0.191 \\
\hline BACFDI02 & Share of foreign capital in assets ownership in downstream industries (NACE 2-digit level) & 22736 & 0.453 & 0.086 & 48782 & 0.408 & 0.049 \\
\hline FORFDIO2 & Share of foreign capital in assets ownership in upstream industries (NACE 2-digit level) & 22736 & 0.441 & 0.129 & 48782 & 0.367 & 0.053 \\
\hline HORFDIO2TN & Share of foreign capital in turnover in the industry the firm belongs to (NACE 2-digit level: nested variable) & 22736 & 0.492 & 0.183 & 48782 & 0.290 & 0.122 \\
\hline HORFDIO3TN & Share of foreign capital in turnover in the industry the firm belongs to (NACE 3-digit level: nested variable) & 22736 & 0.332 & 0.250 & 48782 & 0.178 & 0.199 \\
\hline HORFDI04T & Share of foreign capital in turnover in the industry the firm belongs to (NACE 4-digit level) & 22736 & 0.367 & 0.241 & 48782 & 0.243 & 0.173 \\
\hline BACFDIO2T & Share of foreign capital in turnover in downstream industries (NACE 2-digit level) & 22736 & 0.421 & 0.083 & 48782 & 0.362 & 0.045 \\
\hline HORFDIO2VN & Share of foreign capital in added-value in the industry the firm belongs to (NACE 2-digit level: nested variable) & 22736 & 0.490 & 0.171 & 48782 & 0.307 & 0.143 \\
\hline HORFDIO3VN & Share of foreign capital in added-value in the industry the firm belongs to (NACE 3-digit level: nested variable) & 22736 & 0.346 & 0.255 & 48782 & 0.205 & 0.225 \\
\hline HORFDI04V & Share of foreign capital in added-value in the industry the firm belongs to (NACE 4-digit level) & 22736 & 0.364 & 1.415 & 48782 & 0.258 & 0.184 \\
\hline BACFDIO2V & Share of foreign capital in added-value in downstream industries (NACE 2-digit level) & 22736 & 0.440 & 0.083 & 48782 & 0.380 & 0.045 \\
\hline HORFDIO2EN & Share of foreign capital in equity capital in the industry the firm belongs to (NACE 2-digit level: nested variable) & 22736 & 0.572 & 0.194 & 48782 & 0.385 & 0.199 \\
\hline HORFDIO3EN & Share of foreign capital in equity capital in the industry the firm belongs to (NACE 3-digit level: nested variable) & 22736 & 0.406 & 0.286 & 48782 & 0.218 & 0.241 \\
\hline HORFDI04E & Share of foreign capital in equity capital in the industry the firm belongs to (NACE 4-digit level) & 22736 & 0.406 & 0.245 & 48782 & 0.280 & 0.227 \\
\hline BACFDIO2E & Share of foreign capital in equity capital in downstream industries (NACE 2-digit level) & 22736 & 0.475 & 0.101 & 48782 & 0.397 & 0.052 \\
\hline HORFDIO2WN & Share of foreign capital in employment in the industry the firm belongs to (NACE 2-digit level: nested variable) & 22736 & 0.337 & 0.167 & 48782 & 0.156 & 0.077 \\
\hline HORFDIO3WN & Share of foreign capital in employment in the industry the firm belongs to (NACE 3-digit level: nested variable) & 22736 & 0.219 & 0.189 & 48782 & 0.112 & 0.128 \\
\hline HORFDI04W & Share of foreign capital in employment in the industry the firm belongs to (NACE 4-digit level) & 22736 & 0.259 & 0.188 & 48782 & 0.140 & 0.114 \\
\hline BACFDI02W & Share of foreign capital in employment in downstream industries (NACE 2-digit level) & 22736 & 0.311 & 0.078 & 48782 & 0.247 & 0.043 \\
\hline \multicolumn{8}{|l|}{ Input variable } \\
\hline K & Total assets (natural logarithm) & 22696 & 11.321 & 1.513 & 48737 & 11.185 & 1.451 \\
\hline$L$ & Annual average number of employees (natural logarithm) & 22736 & 3.027 & 1.043 & 48782 & 2.609 & 0.836 \\
\hline$M$ & Total amount of intermediate materials (natural logarithm) & 22690 & 11.349 & 1.519 & 48712 & 11.590 & 1.529 \\
\hline$K / L$ & Total assets per employee (natural logarithm) & 22730 & 8.382 & 1.026 & 48673 & 8.673 & 1.162 \\
\hline \multicolumn{8}{|l|}{ Control variable } \\
\hline FS & Ownership share of foreign investors & 22736 & 0.047 & 0.182 & 48782 & 0.027 & 0.136 \\
\hline GS & Government ownership share & 22736 & 0.006 & 0.070 & 48782 & 0.006 & 0.072 \\
\hline EXPPRO & Proportion of exports in total turnover & 22736 & 0.124 & 0.260 & 48782 & 0.035 & 0.142 \\
\hline HHI & Herfindahl index (NACE 4-digit level) & 22736 & 0.104 & 0.148 & 48782 & 0.038 & 0.062 \\
\hline
\end{tabular}

